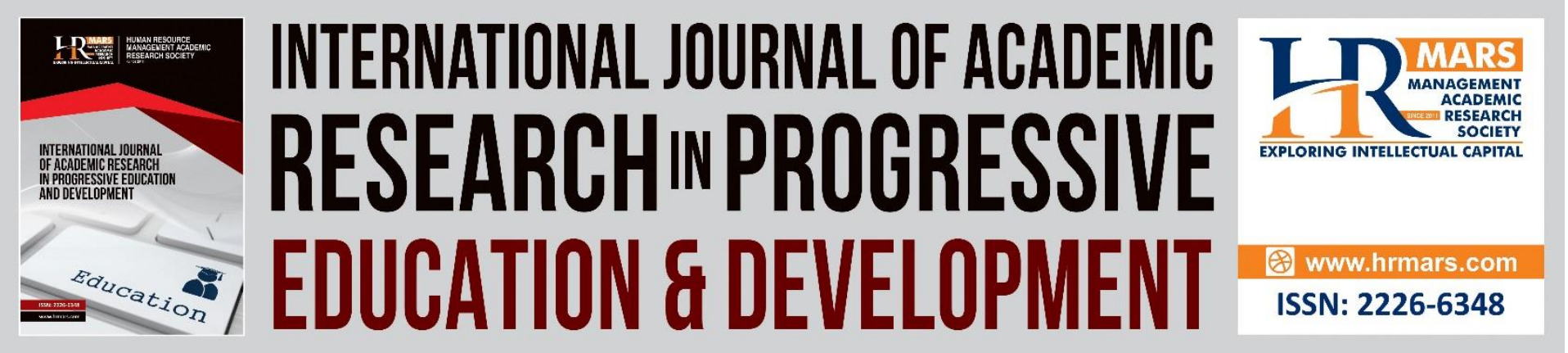

\title{
Teachers' and Students' Perceptions towards Distance Learning during the Covid-19 Pandemic: A Systematic Review
}

\section{Tian Wei Koet, Azlina Abdul Aziz}

To Link this Article: http://dx.doi.org/10.6007/IJARPED/v10-i3/11005

DOI:10.6007/IJARPED/v10-i3/11005

Received: 10 June 2021, Revised: 12 July 2021, Accepted: 25 July 2021

Published Online: 20 August 2021

In-Text Citation: (Koet \& Aziz, 2021)

To Cite this Article: Koet, T. W., \& Aziz, A. A. (2021). Teachers' and Students' Perceptions towards Distance Learning during the Covid-19 Pandemic: A Systematic Review. International Journal of Academic Research in Progressive Education and Development, 10(3), 531-562.

Copyright: (c) 2021 The Author(s)

Published by Human Resource Management Academic Research Society (www.hrmars.com)

This article is published under the Creative Commons Attribution (CC BY 4.0) license. Anyone may reproduce, distribute, translate and create derivative works of this article (for both commercial and non-commercial purposes), subject to full attribution to the original publication and authors. The full terms of this license may be seen at: http://creativecommons.org/licences/by/4.0/legalcode

Vol. 10(3) 2021, Pg. 531 - 562

http://hrmars.com/index.php/pages/detail/IJARPED

JOURNAL HOMEPAGE

Full Terms \& Conditions of access and use can be found at http://hrmars.com/index.php/pages/detail/publication-ethics 


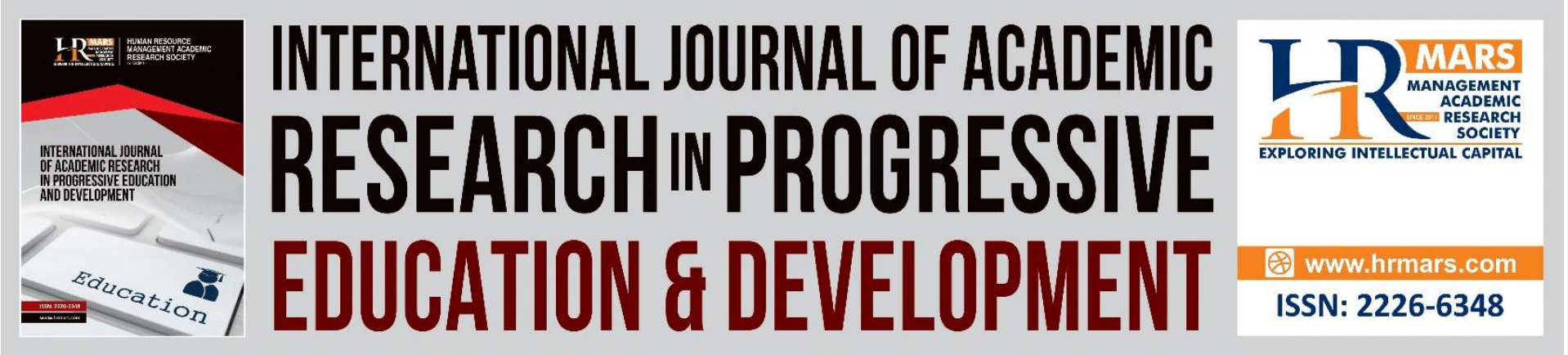

\title{
Teachers' and Students' Perceptions towards Distance Learning during the Covid-19 Pandemic: A Systematic Review
}

\author{
Tian Wei Koet, Azlina Abdul Aziz \\ Faculty of Education, Universiti Kebangsaan Malaysia \\ Email: twkoet.10415@gmail.com, azlina1@ukm.edu.my
}

\begin{abstract}
Covid-19 has brought about a drastic global shift in the education sector, both in terms of teaching as well as learning. Within a short time frame, the very direction of future education has potentially changed. With this epiphany, this paper serves to present a systematic review of relevant published studies on teachers' and students' perception towards distance learning during the Covid-19 pandemic from the year 2021 to 2021. Following a systematic search and application of inclusion and exclusion criteria, twenty-two studies were selected and subjected to data analysis and synthesis for the systematic review. Google Scholar, ScienceDirect, ProQuest Education Journal, Educational Resources Information Centre (ERIC), and SAGE Journal databases were used to identify relevant studies. Despite many inadequacies and drawbacks of the emergency and a less-rigorously planned curriculum than traditional face-to-face teaching and learning sessions, the incorporation of remote learning is unavoidable during the pandemic, according to the findings of relevant studies. The findings also reveal that a variety of factors influence teachers' and students' impressions of distant learning, including the availability of facilities and networks, ICT abilities, administrative and learning assistance, learning preferences, and learning environment. By understanding how distance learning is perceived, future policy makers and key stakeholders can be better equipped to develop a more comprehensive curriculum.
\end{abstract}

Keywords: Teachers' Perception, Students' Perception, Distance Learning, Covid-19 Pandemic

\section{Introduction}

\section{Background of the Study}

The rapid spread of the novel coronavirus disease (Covid-19) since December 2019 from Wuhan, China, had caused ongoing adverse effects to the world, to the extent that the World Health Organization (WHO) had announced it as a pandemic on the 11th of March 2020 (WHO, 2020; Kapasia et al., 2020). The deadly dispersion of the pandemic has sparked panic worldwide, including in Malaysia (WHO, 2020). Many countries around the world, including Saudi Arabia, the Philippines, the UK, and Australia, have declared a state of emergency to prevent the epidemic from spreading further (Norlin, 2020). Similarly, as the number of cases 
rose, the Malaysian federal government had to make a drastic decision by imposing a Movement Control Order (PKP) nationwide starting 18th March 2020 (Abdul Halim, 2020). Different stages of the Movement Control Order were introduced with varying imposed restrictions to combat the virality of Covid-19. Among the numerous conditions introduced, infection management and physical distancing are critical elements for preventing the virus from spreading further and curbing the pandemic crisis. Many countries, including Malaysia, have enforced compulsory physical distance policies, resulting in national level school and university closures. According to the data collected and published by UNESCO (2020), as of the $1^{\text {st }}$ of June 2020, the nationwide closures, which involved 149 country-wide closures, have impacted approximately $68 \%$ of the world's student population, which is roughly equivalent to $1,190,137,755$ students.

In accordance with this policy, educational institutions at all levels, from primary to tertiary, were required to make suitable and timely changes in order to continue to provide education and maintain student academic advancement. The teaching and learning activities were immediately shifted to full distance learning. Although distance and online learning has been seen as part of the educational tool adapted to facilitate existing face-to-face learning, it has not been widely used as the sole channel to deliver the whole curriculum of the school year. While it is believed that information technology has made it possible for those who have access to continue the learning process during lockdown (Zwain, 2019), it is undeniable of the existence of the digital gap between rural and urban areas, for example, in Malaysia, is at 30:70 (Muin, 2020).

With there being different standards of technological availability and connectivity in various areas in any given country, the experience of distance and online learning for teachers and students will vary across the region. The perception of teachers and students in areas with lower levels of development may favour onsite classes instead of those from urbanized areas with better connectivity. The overnight shift from the conventional physical contact classes to full distance learning may be a less jarring experience for teachers who are familiar with the digital realm. The students' perceptions towards their learning journey will also differ based on their learning experience with their teachers.

\section{Statement of Problem}

Due to the closure of educational institutions, instant transition from face-to-face classes to distance learning sessions took place. Educators, teachers, and lecturers were compelled to conduct classes in front of their computers, just as they would in real classrooms. Many educators had never conducted sessions in an online setting before, necessitating the acquisition of a diverse range of skills in a short amount of time. They also had to adjust the content and structure of their services and choose the best strategies for engaging their students in a virtual setting. As the educators scrambled into the shift towards distance learning, they experienced constraints such as connection problems, pedagogy, and evaluation methodologies, in addition to the need to adapt and transfer their teaching content to suit the distance learning mode.

Beyond the complications afflicting educators, students were also affected by the abrupt transition to distance learning. Students who were used to face-to-face contact had to quickly adjust to distance learning and the online setting, resulting in some students quickly feeling bored and disengaged from the unfamiliar curriculum. Others have experienced more technological limitations such as a lack in the availability of stable internet connections as well as hardware limitations or obsolete devices. Furthermore, the various modifications and 
constraints associated with Covid-19, as well as the related psychosocial stresses that students and educators have been encountering, increased the problems of fast-moving to distant learning (Marshall \& Wolanskyj-Spinner, 2020).

The pandemic has triggered the accelerated transition of conventional classroom studies towards embracing distance and online learning. It is imperative to understand the influence of teacher and student perception towards distance learning to cope with the genuine possibility that distance learning will be a crucial part of the direction of future education. Educators and students need to increase networking, foster meaningful and effective connections, and enhance their communication effectiveness prior to, during, and after their online classes (Li \& Bailey, 2020). This experience will influence how they create meaning and reflect upon learning and teaching (Carlson, 2020). Through the systematic literature review of articles related to the perception of teachers and students on distance learning, it is believed that clarity on the accurate impression of both parties will help policymakers in the MOE develop, adapt, and adopt a better curriculum to meet the needs of the students. On a more local scale, the findings from this review can also bridge the gap between student expectations and the lessons conducted via distance learning.

\section{Research Objective and Research Questions}

The novelty of the circumstance, as well as how the teachers and students have been adjusting to this situation, constitute excellent opportunities for investigation, given that most research studies, to date, have been conducted in typical 'face-to-face' educational environments. It is crucial to examine and reflect on this experience to better prepare for the potentiality of reoccurrence or the experiencing of other emergencies that necessitate a rapid transition to distance teaching and learning. Furthermore, the lessons learned through this abrupt shift in schooling can positively transform education in the aftermath of the pandemic.

The main objective of this systematic review is to present a synthesis of empirical evidence found in the related past studies on teachers' and students' perception of distance learning during the pandemic to scholars and researchers so that further directions, intervention, and modification of the current existing distance learning curriculum can be improved. This study is conducted to answer two research questions:

a) What are the teachers' perceptions towards distance learning during the Covid19 pandemic? and

b) What are the students' perceptions towards distance learning during the Covid19 pandemic?

\section{Literature Review \\ Definition of Distance Learning}

The term' distance learning' is not a new term in the academic field. It was first coined by The United States Distance Learning Association as its formal definition of 'distance learning' as 'the acquisition of knowledge and skills through mediated information and instruction, encompassing all technologies and other forms of learning at a distance.' The pandemic has somehow demanded students and educators to follow the new norms, which is to accept the implementation of Open Distance Learning (ODL). When students and instructors do not meet in person, and the learning process is handled through technology, it is referred to as distance learning; students complete their tasks virtually without attending physical or face-to-face class (Van Wart et al., 2019, Allam et al., 2020). 
It is also worth mentioning that there are several words related to distance learning which are often used interchangeably with distance learning. This includes e-learning, online learning, and virtual studies. Clark and Mayer (2016) categorized e-learning into two distinct types: synchronous e-learning and asynchronous e-learning. Synchronous learning refers to the almost instantaneous educator-led teachings through real-time communications between teachers and their students, similar to that of the conventional face-to-face classroom environment. This learning model would utilize any online-based platforms that allow for interactive, virtual communications such as webinars, virtual classrooms, or instant messaging. The liberal use of cameras and microphones in this approach helps further strengthen teacher-student engagements, bolster group identity, and allows for timely feedback from teachers (Brown et al., 2016; Clouder et al., 2006; Falloon, 2011).

Unlike synchronous learning, which mirrors the traditional classroom formula, Moore (2016) defines asynchronous learning as the learning process where students can access learning materials at their convenience, be it in time or location. Technology today has advanced to the point that content delivery over the Internet is more flexible, and instructors can make use of a variety of resources to enhance the learning experience. Anderson (2011) mentions that instructors can update online materials at any time and place, and students will be able to see the changes reflected immediately. Students' needs and the assignment of suitable materials to reach learning goals can be carried out using online learning systems as well (Nursalina \& Firawati, 2021).

Distinctive features of online and distance education include the separation of teachers and students, the adaptation of a computer network to share educational resources, the provision of two-way communication via a computer network, and the influence of an educational institution (Paulsen, 2002). As distance learning is adapted because face-to-face learning could not be done, initially aimed for students who cannot attend physical lessons at the university, it is the most suitable choice or the only option that stood out during the pandemic to ensure the continuation of education (Lassoued et al., 2020). While distance learning has a whole host of benefits on paper, in practice, Coman et al. (2019) mentions that constant use of online education has resulted in some students experiencing a lack of motivation, poor communication experiences, isolation, lack of quality interactions, and also reduced engagement due to poor accessibility in a remote area and lack of fund.

\section{Education During the Pandemic}

People's unfettered commitment to strict preventative measures such as social distancing, following medically advised quarantine processes, and embracing cleanliness and sanitation can help control the Covid-19 pandemic to a greater extent (Khachfe et al., 2020). Most governments worldwide have temporarily closed down educational institutions to prevent and curb the spread of the Covid-19 pandemic. Once national social distancing directives were established, several countries' educational institutions were required to use remote learning settings and other e-learning tools (Gewin, 2020). Schools, colleges, and institutions are closing rapidly around the world, and authorities are working to replace them with online learning programmes (Clancy \& Sentence, 2020).

Before the unparalleled Covid-19 pandemic struck the world, the education system was primarily reliant on teachers' competence to teach any of the disciplines or courses in the institution's main focus of the curriculum. However, during the pandemic, the traditional method of teaching and learning had been entirely overtaken by online and distance learning (Karuppannan \& Mohammed, 2020), and teachers who had been striving for proficiency in 
face-to-face classroom teaching were scrambling to equip themselves to be online instructors during the pandemic period (Shahzad et al., 2020). This happened because continuing education delivery through alternate learning and teaching channels jumped to the top of the priority list for institutions hoping to mitigate the effects of the crisis on education.

Education during the pandemic has given distance learning an entirely new meaning. It is the only method that could ensure the sustainability of education while fighting with the spread of the pandemic, which contrasts with being used as a supplementary approach or alternative resources (Yunus et al., 2021). When no other options are available, online and distance education, as the only employable method, becomes the most prominent pillar of support to the newly formed education curriculum amidst the chaos. Across the world, governmental support in the forms of educational technology (including online learning, radio, television, texting) to support access to remote learning during the Covid-19 pandemic was seen in many countries. The reactions, however, varied significantly depending on one's income level. Only about a quarter of low-income countries offer any remote learning, and the majority of those that do use TV and radio, whereas close to $90 \%$ of high-income countries offer remote learning alternatives, practically all of which are available online (UNESCO, 2020).

The Ministry of Education in China, which was the country most devastated by the pandemic at the start of its breakout, has started a programme to give flexible online learning to over 270 million students at home (Huang, 2020). The Bangladesh government collaborates with UNICEF and provides parents and caregivers with financial support and information to help implement effective remote learning programmes so that students learn from the Bangladesh Television YouTube channel (World Bank, 2020). Apart from setting up EduwebTV and making digital textbooks available online by the Ministry of Education in Malaysia, the government also provided financial aid to support the telecommunication plan and the provision of gadgets to the most vulnerable students (Rasit et al., 2021). There are some countries, however, that are unprepared for the adoption of emergency remote education. Despite the fact that many schools in the Philippines were in a traditional classroom environment before to Covid-19, the Philippines government is still striving to provide alternate delivery education during this crisis (Toquero, 2021).

\section{Challenges in Teaching and Learning}

It has been a challenging experience for both students and teachers alike during the entire Covid-19 pandemic. As governments worldwide struggled to combat the virus through every possible means, information regarding Covid-19 evolved as doctors and scientists gained a deeper understanding with every passing day. This has led to constant shifts in the various strict preventive measures established by the authorities to manage the spread of the pandemic. This invariably caused ripples of effect across the education landscape due to the closure of educational institutions and the subsequent Standard Operating Procedures introduced during reopening of schools. This, of course, rings true for Malaysia as well, especially in the initial MCO 1.0 on the 18th March 2020, where schools and higher learning institutes were initially closed and then opened again for a short span (Abdul Halim, 2020). Educators and students had to scramble to embrace e-learning, then transition back to a brief span back in schools for some states before the spike in Covid-19 cases in 2021 forced a shutdown again. However, this is far from the only challenge to surface.

Concerning research on the teaching and learning platform for access to communication technology among teachers and students, which the Education Ministry of 
Malaysia conducted in early 2021, it showed that almost up to 36.9 percent (approximately 1.85 million) of Malaysian students nationwide still do not possess any electronic devices to facilitate distance learning. Compounding this finding, only 6 percent of students have their own personal computers, 5.67 percent own tablets, 9 percent own laptops, and around 46 percent have smartphones (Chan, Karim \& Yusof, 2020). As classes may span long sessions depending on the level of education, not being equipped with the suitable device severely hampers the effectiveness of the student's learning process. When the process to learn becomes tiresome, students will feel unmotivated to learn in such circumstances because they are constantly confronted with a computer (Toquero, 2020). Wazzan (2020) summarized and addressed the present challenges as follows, 'Students are distracted, teachers are not adequately trained, and our technology amenities is far from fully ready to cooperate. It is a serious concern that some governments and providers are under pressure to move too fast to ensure uninterrupted learning, with insufficient medium-term planning or ramp-up time.'

Sintema (2020) notes that the lack of contact hours and opportunities to have meaningful consultations with teachers who face difficulties will cause a further drop in academic performance. This view is supported by findings from other researchers as well, where a significant problem highlighted for distance learning is the lack of engagement with educators (Lestiyanawati \& Widyantoro, 2020; Ariyanti, 2020). Students need two-way communication in their education journey to thrive, which can be challenging to achieve through distance learning alone. To add to this, some students have shared that the learning atmosphere at home is not conducive to their studies and that they are expected to contribute to household chores during the lockdown, which negatively impacted their studies, making them depressed and despondent (Mishra, Gupta, \& Shree, 2020). A suitable working environment has often been associated as a contributing factor to an individual's job satisfaction and performance from the teacher's side. Teachers also require an optimum home working environment to ensure teaching effectiveness (Raziq \& Maulabakhsh, 2015). However, teachers working from home are just as likely to be distracted by their housework, especially those with new families and raising young children. (Yew \& Tan, 2020)

\section{Opportunities for Teaching and Learning}

Although distance learning immediately posed many challenges in teaching and learning when the Covid-19 pandemic hit, it also offered a lot of opportunities to both students and teachers. One of them is the unlimited resources and vast opportunities for collaboration and networking (Yunus et al., 2021). Due to scarce ready-made resources over the abrupt transition to distance learning, teachers bustled into actively collaborating with one another at a local to international level to kickstart and improve their online pedagogy. As instructors, parents, and children share comparable experiences, there are unrivaled chances for collaboration, creative solutions, and a desire to learn from others and try new methods (Doucet et al., 2020). Apart from collaborating with other educators, Kahoot, Quizizz, Quizlet, and Plickers are examples of established online game-based learning tools that enable teachers to assess student's learning progress in a fun way. These online gamebased learning resources help pupils learn more effectively (Zarzycka-Piskorz, 2016; Yew \& Tan, 2020).

Distance learning can be beneficial to students too. In the context of English as a second language, Krashen (1985) claimed that people could learn a second language provided they understand it and have a low affective filter that allows the input to get through. Similarly, by using e-learning, ESL students can engage freely and safely in cyberspace without 
feeling inferior or making mistakes, resulting in a low-filter learning environment (Yen \& Mohamad, 2021). Researchers looked into students' engagement in College English classes in China in a study by Huang (2021). They discovered that pupils had an extrinsic goal orientation when studying English, comparable to how they were motivated in face-to-face classes. More crucially, compared to face-to-face learning, distant learning, which effectively lowered their affective filters, allowed students to communicate with their instructor and peers more frequently.

It is undeniable that during the pandemic, the use of the Internet in education has resulted in a unique and quick development in educational science, which has brought about how teachers and students perform and achieve goals in the classroom (Ali et al., 2018). Before the pandemic, terms such as 'a world without papers' and 'universities without walls' have emerged at the international level to describe the Internet and information networks, future-oriented educational institutions, electronic universities and schools, and the Covid-19 outbreak is the proof that such ideologies are possible to ensure the sustainability of education under various strict regulations to curb the pandemic (Doucet et al., 2020). In short, teachers and students with a fixed mindset find it challenging in adapting and adjusting, but students with a growth mindset adapt quickly to new situations. Like conventional learning contexts, there is no one-size-fits-all methodology for distance learning (Pokhrel \& Chhetri, 2021).

\section{Methodology}

The procedures that involved four stages and eight activities (steps) proposed by Okoli (2015), A Guide to Conducting a Standalone Systematic Literature Review, were adopted to conduct this review. The first stage, i.e., planning the review, was carried out to identify the purpose of the review and develop the review protocol. Then, I proceeded to the next stage, the selection stage. In step three, I applied a practical screening process where I screened for inclusion, identifying studies related to teacher and student's perception about distance teaching during the pandemic, which I considered for review and eliminated other studies. The eliminated studies were not selected due to the fact that they did not meet the criteria which would be outlined.

Then, I proceeded to step four, the search for literature. The following online bibliographic databases, namely Google Scholar, ScienceDirect, ProQuest Education Journal, Educational Resources Information Centre (ERIC), and SAGE Journals, were used to identify peer-reviewed research studies or articles written in English published between the year 2020 to 2021 (research relevant to the current studies which are related to distance education during the pandemic). The combination of terms used to search for the past associated studies in the keywords fields of the above databases was: (perception, distance learning, Covid-19 OR pandemic). The 'related terms' box was checked, and, in each database, searches were refined by 'research domains,' 'document types,' 'language' and 'publication years'. The initial search yielded 283 results for ScienceDirect, 850 results for SAGE Journals, 1234 results for ERIC, 1584 results for ProQuest, and 41700 results for Google Scholars.

For the third stage, the abstracts of the studies (step five) were screened with regards to the inclusion criteria (step six) as following:

1. All the participants or respondents in this study could be students at their primary, secondary, or tertiary level or teachers of primary, secondary, or tertiary level institutions. 
2. The studies focus on collecting data pertaining to distance education during the Covid19 pandemic.

3. The studies focus on investigating teachers' perception, students' perception, or both teachers' and students' perceptions.

4. The studies conducted followed the assumption that all studies were carried out via distance learning without the availability of face-to-face interactions.

5. The studies are empirical and either employed qualitative, quantitative, or mixedmethod research design as more methodologically rigorous studies are needed.

However, it was difficult to exclude journals or articles based on the titles and abstracts of the studies solely; hence, moving on to step seven in stage four, synthesizing the studies, the introduction and conclusion sections of the whole article were being shortlisted. Then, the articles are being reviewed accordingly (step eight).

\section{Results and Discussion}

In this section, the results from the selection process of the research articles found will be discussed in detail. After the eight steps of selecting the eligible articles for review, twentytwo journal articles were found to be suitable to be used in this systematic review due to the nature of the respective studies. A total of five studies about teachers and students' perceptions towards distance learning during the Covid-19 pandemic, eight studies about teachers' perceptions towards distance learning during the Covid-19 pandemic, and nine studies about students' perception towards distance learning during the Covid-19 pandemic from the year 2020 and 2021 were shortlisted. Out of the twenty-two shortlisted published articles, fourteen were published in 2020, and eight were published in 2021. The number of studies by countries is summarized in Figure 1 and the educational level at which the studies are done is summarized in Figure 2. The empirical evidence to support the teachers' and students' perceptions towards distance learning during the Covid-19 pandemic are summarised in Table 1, 2, and 3.

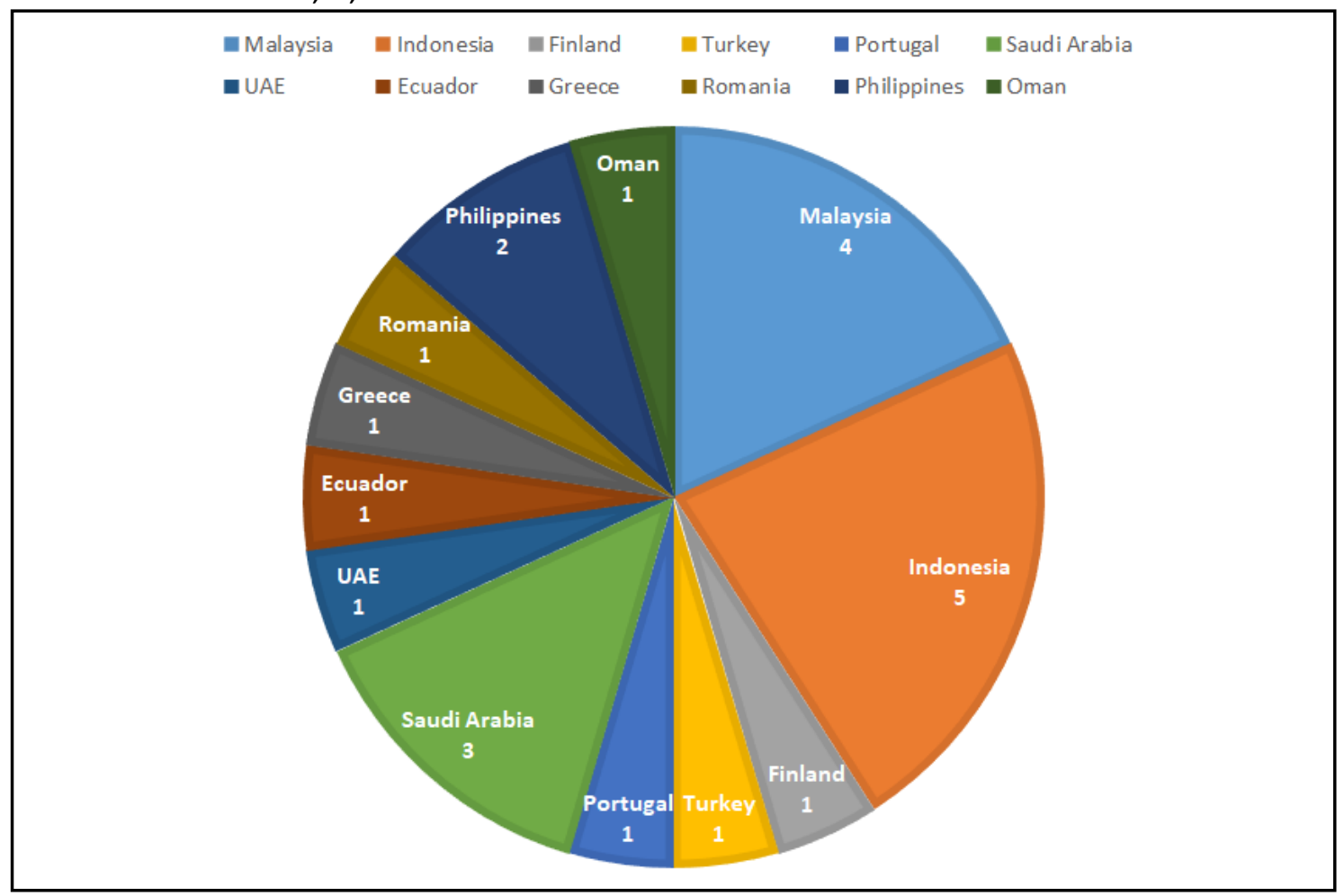

Figure 1 The number of studies by country 
The number of studies by country is shown in Figure 1. In light of the review writing, the researcher found that up to the current date, there are still very limited empirical studies on teachers' and students' perceptions towards distance learning during the pandemic, as the outbreak started in early 2020. From the twenty-two articles shortlisted, there were more studies from Indonesia, Malaysia, and Saudi Arabia than from other countries. This shows that it is a concern for many researchers and stakeholders about the perceptions of teachers and students on distance learning during the pandemic. Of all selected studies, 50\% were related to ESL teaching and learning context. This shows that research on distance learning perceptions is being emphasized in many countries where English is spoken as a second language.

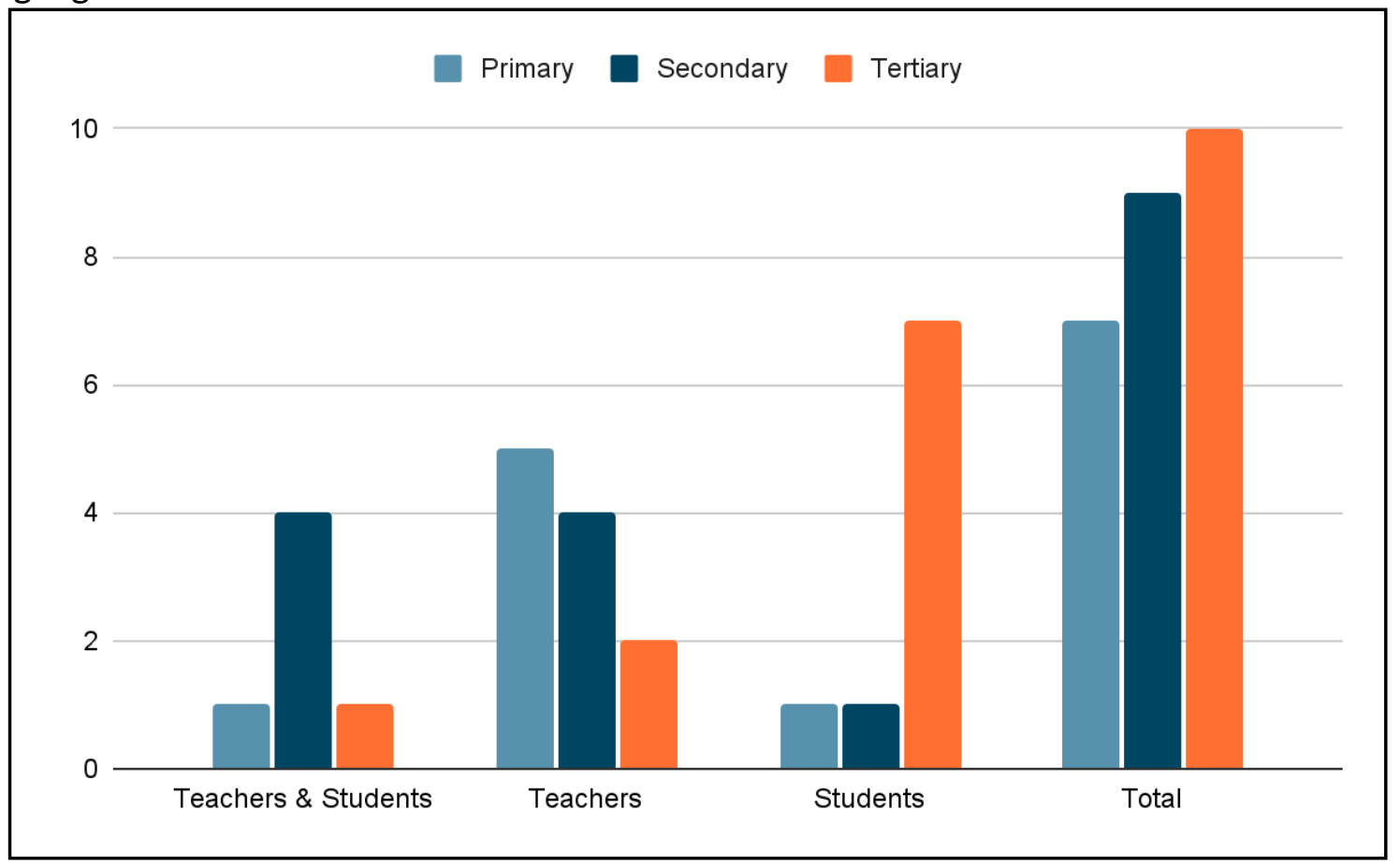

Figure 2 Educational level at which the studies are done

The educational level at which the studies are done is shown in Figure 2. The graph shows that the selected studies include participants from primary education to tertiary education level. Studies related to teachers and students showed that most studies were done from the perspectives of teachers and students from secondary schools. For studies related to teachers' perspectives, more studies were done on primary school teachers than educators from secondary and tertiary education institutions. From the graph, it is evident that although there were studies done on teacher's perspectives for primary and secondary schools, there were minimal studies done on primary and secondary school students. It can also be concluded that the data collected from the studies on primary and secondary school students cannot be generalized. Nevertheless, it is understandable that perhaps data cannot be collected up to this point in time due to the lack of a channel to collect data from participants. It is hoped that more research will be carried out on these two levels so that more insights can be explored to further understand the students' perspective on distance learning during the pandemic. 
Table 1: Summary of past related studies which focussed on both teachers' and students' perceptions.

\begin{tabular}{|c|c|c|c|c|c|}
\hline $\begin{array}{l}\text { Article } \\
\text { / } \\
\text { Study }\end{array}$ & $\begin{array}{l}\text { Aim of } \\
\text { study }\end{array}$ & $\begin{array}{l}\text { Number } \\
\text { of } \\
\text { participa } \\
\text { nts }\end{array}$ & $\begin{array}{l}\text { Researc } \\
\text { h design }\end{array}$ & Findings & $\begin{array}{l}\text { Suggestions/F } \\
\text { uture research }\end{array}$ \\
\hline $\begin{array}{l}\text { Niemi } \\
\& \\
\text { Kousa } \\
(2020)\end{array}$ & $\begin{array}{l}\text { 1. Describe } \\
\text { students' } \\
\text { and } \\
\text { teachers' } \\
\text { perception } \\
\text { s of } \\
\text { distance } \\
\text { schooling } \\
\text { and what } \\
\text { kind of } \\
\text { differences } \\
\text { there were } \\
\text { between } \\
\text { the two } \\
\text { groups' } \\
\text { perception } \\
\text { s. }\end{array}$ & $\begin{array}{l}1 . \\
\text { Question } \\
\text { naires } \\
\text { (258 } \\
\text { students } \\
\& \quad 51 \\
\text { teachers) } \\
\text { 2. Open- } \\
\text { ended } \\
\text { assessm } \\
\text { ent } \\
\text { (30 } \\
\text { students } \\
\& \quad 11 \\
\text { teachers) }\end{array}$ & $\begin{array}{l}\text { Mixed } \\
\text { method } \\
\text { s: } \\
\text { 1. Short } \\
\text { Questio } \\
\text { nnaires } \\
\text { (4 times } \\
\text { on } \\
\text { differen } \\
\text { t dates) } \\
\text { 2. Freely } \\
\text { describ } \\
\text { e } \\
\text { experie } \\
\text { nces } 5 \\
\text { times }\end{array}$ & $\begin{array}{l}\text { Teachers: } \\
\text { - Generally positive } \\
\text { perception and additional } \\
\text { worries over difficulties in } \\
\text { creating genuine } \\
\text { interactive relationships } \\
\text { with all students, } \\
\text { pedagogical and } \\
\text { assessment methods. } \\
\text { Teachers think that } \\
\text { students do not have } \\
\text { enough work, but } \\
\text { students believe } \\
\text { workloads are too heavy. } \\
\text { Students: generally, but } \\
\text { - Positive gene } \\
\text { self-management in } \\
\text { learning gets more } \\
\text { challenging over time. } \\
\text { Distance learning lacks } \\
\text { the social relationships } \\
\text { and interactions that } \\
\text { bolster motivation. } \\
\text { Students generally prefer } \\
\text { face-to-face learning. }\end{array}$ & $\begin{array}{l}\text { - Apply the } \\
\text { study } \\
\text { framework } \\
\text { to other } \\
\text { sectors. } \\
\text { - Apply } \\
\text { demograp } \\
\text { hic data in } \\
\text { the } \\
\text { findings to } \\
\text { explore if } \\
\text { different } \\
\text { demograp } \\
\text { hics have } \\
\text { different } \\
\text { perception } \\
\text { s. } \\
\text { Apply } \\
\text { alternative } \\
\text { data } \\
\text { collection } \\
\text { tools. } \\
\text { Explore the } \\
\text { effect of } \\
\text { lesser } \\
\text { hands-on } \\
\text { experience } \\
\text { on the } \\
\text { learning } \\
\text { outcome } \\
\text { satisfactio } \\
\mathrm{n} \text { of the } \\
\text { students }\end{array}$ \\
\hline
\end{tabular}




\begin{tabular}{|c|c|c|c|c|c|}
\hline $\begin{array}{l}\text { Hebeb } \\
\text { ci, } \\
\text { Bertiz, } \\
\text { \& Alan } \\
(2020)\end{array}$ & $\begin{array}{l}1 . \text { To } \\
\text { determine } \\
\text { the views } \\
\text { of students } \\
\text { and } \\
\text { teachers } \\
\text { on distance } \\
\text { education } \\
\text { activities } \\
\text { they } \\
\text { participate } \\
d \text { in the } \\
\text { covID-19 } \\
\text { pandemic. }\end{array}$ & $\begin{array}{l}20 \\
\text { students } \\
\& \quad 16 \quad 16 \\
\text { teachers } \\
\text { from } \\
\text { secondar } \\
\text { y schools } \\
\text { and high } \\
\text { schools } \\
\text { in Turkey }\end{array}$ & $\begin{array}{l}\text { Qualitat } \\
\text { ive } \\
\text { researc } \\
\text { h: A } \\
\text { case } \\
\text { study }\end{array}$ & 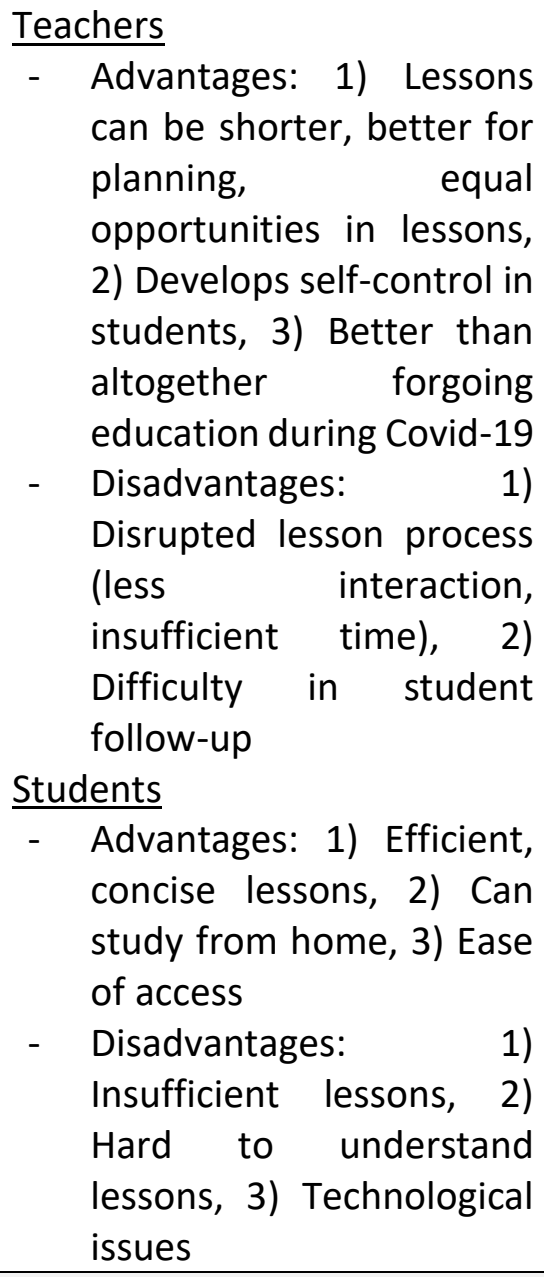 & $\begin{array}{l}\text { Compare } \\
\text { distance } \\
\text { education } \\
\text { programs } \\
\text { run by } \\
\text { different } \\
\text { countries. } \\
\text { Compare } \\
\text { the } \\
\text { different } \\
\text { approache } \\
\text { s used } \\
\text { between } \\
\text { public vs. } \\
\text { private } \\
\text { schools } \\
\text { and the } \\
\text { perception } \\
\text { s of the } \\
\text { students \& } \\
\text { teachers. }\end{array}$ \\
\hline $\begin{array}{l}\text { Silva \& } \\
\text { Sousa } \\
(2020)\end{array}$ & $\begin{array}{l}1 . \\
\text { Investigate } \\
\text { how } \\
\text { teachers } \\
\text { evaluated } \\
\text { their } \\
\text { performan } \\
\text { ce in the } \\
\text { context of } \\
\text { distance } \\
\text { learning } \\
\text { and } \\
\text { teaching in } \\
\text { the current } \\
\text { pandemic } \\
\text { situation } \\
\text { compared } \\
\text { to the } \\
\text { students' } \\
\text { perception } \\
\text { s about }\end{array}$ & $\begin{array}{l}960 \text { Year } \\
10 \\
\text { students } \\
\text { and } 30 \\
\text { secondar } \\
\text { y school } \\
\text { teachers }\end{array}$ & $\begin{array}{l}\text { Quantit } \\
\text { ative } \\
\text { researc } \\
\text { h } \\
\text { (survey) }\end{array}$ & $\begin{array}{l}\text { Teachers } \\
\text { - Teachers have a more } \\
\text { positive outlook on } \\
\text { distance learning \& } \\
\text { teaching as compared to } \\
\text { their students. } \\
\text { - While the findings from } \\
\text { the teachers say they } \\
\text { encourage participation, it } \\
\text { does not highlight the } \\
\text { ways and tools that they } \\
\text { apply to foster their } \\
\text { student's interest. } \\
\text { Students } \\
\text { - Findings suggest that } \\
\text { students did not find the } \\
\text { transition to distance } \\
\text { learning motivating or } \\
\text { easy, which can be due to } \\
\text { other factors such as lack } \\
\text { of activities/projects. }\end{array}$ & 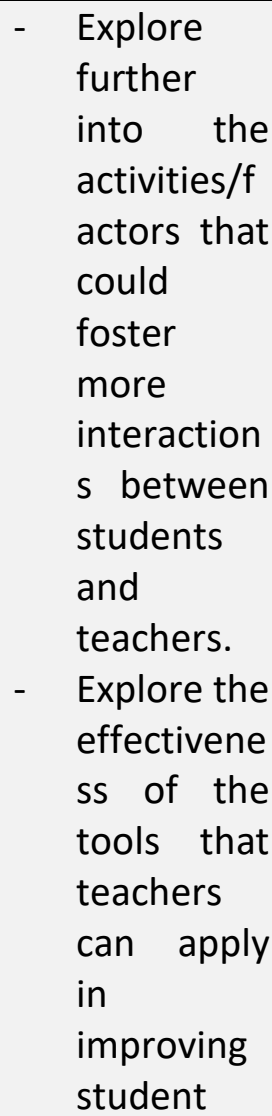 \\
\hline
\end{tabular}


those

topics. interaction

s. This will

help to

guide

student

perception

$s$ more

positively.

\begin{tabular}{|c|c|c|c|c|c|}
\hline $\begin{array}{l}\text { Churiy } \\
\text { ah, } \\
\text { Shollik } \\
\text { han, } \\
\text { Filianti } \\
\text { \& \& } \\
\text { Sakdiy } \\
\text { yah } \\
(2020)\end{array}$ & $\begin{array}{l}\text { 1. Analyse } \\
\text { the } \\
\text { implement } \\
\text { ation of } \\
\text { distance } \\
\text { learning } \\
\text { systems } \\
\text { carried out } \\
\text { by } \\
\text { Indonesian } \\
\text { education } \\
\text { in the } \\
\text { Covid-19 } \\
\text { pandemic } \\
\text { situation. }\end{array}$ & $\begin{array}{l}6 \\
\text { students, } \\
6 \\
\text { teachers } \\
\text { and } \\
3 \text { parents }\end{array}$ & $\begin{array}{l}\text { Qualitat } \\
\text { ive: } \\
1 . \\
\text { Literatu } \\
\text { re study } \\
\text { of } \\
\text { reports } \\
\text { of the } \\
\text { Indones } \\
\text { ian } \\
\text { govern } \\
\text { ment. } \\
2 . \\
\text { depth } \\
\text { intervie } \\
\text { ws }\end{array}$ & $\begin{array}{l}\text { Teachers } \\
\text { - Teachers tend to stutter } \\
\text { about technology, and } \\
\text { parents lack } \\
\text { understanding of the } \\
\text { nature of teaching and } \\
\text { learning activities carried } \\
\text { out at home. } \\
\text { Students } \\
\text { - Students have low self- } \\
\text { regulated learning, so } \\
\text { they are less able to } \\
\text { regulate their distance } \\
\text { learning activities. }\end{array}$ & \\
\hline $\begin{array}{l}\text { Aldoss } \\
\text { ary } \\
\text { (2021). }\end{array}$ & $\begin{array}{l}1 . \quad \text { This } \\
\text { study aims } \\
\text { to explore } \\
\text { university } \\
\text { instructors' } \\
\text { and } \\
\text { students' } \\
\text { perception } \\
\text { s of } \\
\text { utilizing } \\
\text { eLearning } \\
\text { platforms } \\
\text { for } \\
\text { teaching } \\
\text { and } \\
\text { learning } \\
\text { translation } \\
\text { subjects. }\end{array}$ & $\begin{array}{l}22 \\
\text { faculty } \\
\text { member } \\
\text { s \&133 } \\
\text { undergra } \\
\text { duate } \\
\text { students } \\
\text { from the } \\
\text { Departm } \\
\text { ent of } \\
\text { English } \\
\text { Languag } \\
\text { e and } \\
\text { Translati } \\
\text { on } \\
\text { (DELT) at } \\
\text { King } \\
\text { Saud } \\
\text { Universit } \\
\text { y (KSU). }\end{array}$ & $\begin{array}{l}\text { Quantit } \\
\text { ative: } \\
\text { two } \\
\text { separat } \\
\text { e five- } \\
\text { point } \\
\text { Likert } \\
\text { scale } \\
\text { questio } \\
\text { nnaires }\end{array}$ & $\begin{array}{l}\text { Overall neutral findings from } \\
\text { both instructors and students. } \\
\text { Teachers } \\
\text { - } \text { Benefits: elearning was } \\
\text { helpful in the appropriate } \\
\text { delivery of course } \\
\text { content, providing } \\
\text { opportunities for } \\
\text { collaborative work, and } \\
\text { providing more } \\
\text { opportunities to practice } \\
\text { and communicate. } \\
\text { Students } \\
\text { - Agree that online distance } \\
\text { learning enhances their } \\
\text { learning autonomy. They } \\
\text { have more opportunities } \\
\text { to become more active } \\
\text { participants } \\
\text { additional responsibilities } \\
\text { that could ultimately have }\end{array}$ & 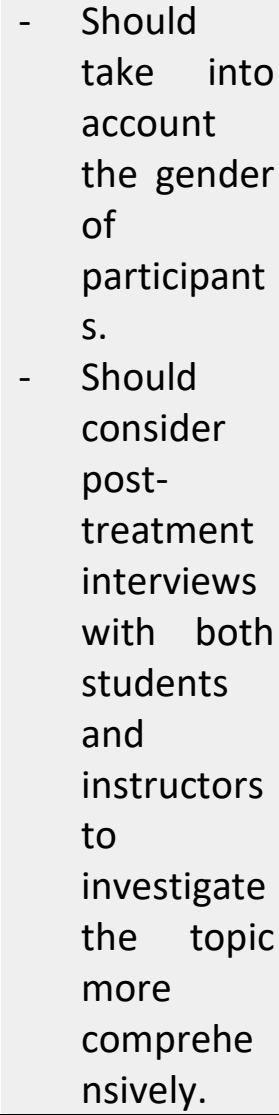 \\
\hline
\end{tabular}


Table 2: Summary of past related studies which focused on teachers' perceptions.

\begin{tabular}{|c|c|c|c|c|c|}
\hline $\begin{array}{l}\text { Article / } \\
\text { Study }\end{array}$ & Aim of study & $\begin{array}{l}\text { Number of } \\
\text { participants }\end{array}$ & $\begin{array}{l}\text { Research } \\
\text { design }\end{array}$ & Findings & $\begin{array}{l}\text { Suggestions/Future } \\
\text { research }\end{array}$ \\
\hline $\begin{array}{l}\text { Omar \& } \\
\text { Hashim } \\
(2021)\end{array}$ & $\begin{array}{l}\text { 1. Investigates the level of } \\
\text { Malaysian English as a } \\
\text { Second language (ESL) } \\
\text { teachers' acceptance of e- } \\
\text { learning for professional } \\
\text { development using the } \\
\text { Technology Acceptance } \\
\text { Model (TAM). } \\
\text { 2. Examines the plausible } \\
\text { relationships amongst } \\
\text { perceived ease of use, } \\
\text { perceived usefulness, } \\
\text { behavioural intention to } \\
\text { use, and actual use of e- } \\
\text { learning for professional } \\
\text { development. }\end{array}$ & $\begin{array}{l}60 \\
\text { Malaysian } \\
\text { ESL } \\
\text { Teachers }\end{array}$ & $\begin{array}{l}\text { Quantitative: } \\
\text { Questionnaire } \\
\text { after online } \\
\text { professional } \\
\text { development } \\
\text { course is } \\
\text { completed }\end{array}$ & $\begin{array}{l}\text { - The more the teacher } \\
\text { perceives that e-learning is } \\
\text { valid, the more likely they } \\
\text { intend to use it for their } \\
\text { professional development. } \\
\text { The higher the intention that the } \\
\text { teacher plans to use e-learning, } \\
\text { the higher the chance of using e- } \\
\text { learning for their professional } \\
\text { development. } \\
\text { ESL teachers in Malaysia are } \\
\text { inclined to accept e-learning for } \\
\text { professional development. } \\
\text { Respondents' relatively high } \\
\text { scores of perceived usefulness } \\
\text { indicate a more open perception } \\
\text { of embracing } \\
\text { instructional technologies and } \\
\text { educational trends. } \\
\text { This bodes well for the probability } \\
\text { of a positive acceptance of e- } \\
\text { learning in Malaysian teachers, } \\
\text { leading to a more positive } \\
\text { perception of using e-learning } \\
\text { tools in their lessons for students. }\end{array}$ & 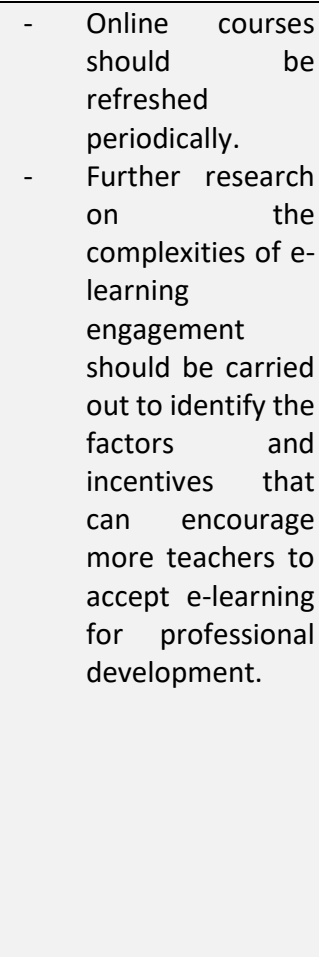 \\
\hline $\begin{array}{l}\text { Yew \& } \\
\text { Tan } \\
(2020)\end{array}$ & $\begin{array}{l}\text { 1. Examined the } \\
\text { relationship between the } \\
\text { factors (i.e., teachers' self- } \\
\text { perceived } \\
\text { competence, the } \\
\text { accessibility to } \\
\text { infrastructure and online } \\
\text { resources, and the } \\
\text { suitability of the working } \\
\text { environment) } \\
\text { 2. Examined teachers' } \\
\text { intention to adopt online }\end{array}$ & $\begin{array}{l}153 \\
\text { Malaysian } \\
\text { ESL teachers } \\
19 \text { male, } \\
134 \text { female } \\
128 \\
\text { government } \\
\text { primary, } 11 \\
\text { government } \\
\text { secondary, } \\
14 \text { private } \\
\text { secondary }\end{array}$ & $\begin{array}{l}\text { Quantitative: } \\
\text { Survey } \\
\text { questionnaire }\end{array}$ & $\begin{array}{l}\text { Teachers' ICT competence was an } \\
\text { essential element in their efforts } \\
\text { to adopt online educational } \\
\text { technologies. } \\
\text { One of the main reasons that } \\
\text { hindered teachers' from adopting } \\
\text { online educational technologies } \\
\text { was the lack of infrastructure } \\
\text { provided at schools. } \\
\text { The participants had adequate } \\
\text { access to the infrastructure and } \\
\text { online resources necessary to } \\
\text { carry out online teaching. }\end{array}$ & \\
\hline
\end{tabular}




\begin{tabular}{|c|c|c|c|c|}
\hline & $\begin{array}{l}\text { educational technologies } \\
\text { in the future. } \\
\text { 3. Identified the factor } \\
\text { that significantly impacts } \\
\text { teachers' behavioural } \\
\text { intention the most. }\end{array}$ & & & $\begin{array}{l}\text { The first experience teaching } \\
\text { from homemade the participants } \\
\text { feel motivated as their working } \\
\text { hours became more flexible. } \\
\text { - Work focuses are distracted by } \\
\text { other household chores, } \\
\text { activities, and responsibilities. }\end{array}$ \\
\hline $\begin{array}{l}\text { Nusalin } \\
\text { a \& } \\
\text { Fitrawat } \\
\text { i (2021) }\end{array}$ & $\begin{array}{l}\text { 1. This study aims to } \\
\text { explore the EFL teachers' } \\
\text { perceptions of English } \\
\text { online learning activities } \\
\text { during the pandemic at } \\
\text { High Schools in Padang. }\end{array}$ & $\begin{array}{l}45 \quad \text { high } \\
\text { school } \\
\text { English } \\
\text { teachers }\end{array}$ & $\begin{array}{l}\text { Quantitative: } \\
\text { Questionnaire }\end{array}$ & $\begin{array}{l}\text { - Most teachers have positive } \\
\text { perceptions regarding online } \\
\text { learning media, strategies, } \\
\text { advantages, and disadvantages. } \\
\text { - Teachers perceived that online } \\
\text { learning media is a practical and } \\
\text { also easy to use technology. } \\
\text { Most teachers admit that using } \\
\text { online learning strategies is more } \\
\text { comfortable than face-to-face } \\
\text { because they can manage their } \\
\text { time flexibility. } \\
\text { More than half of teachers admit } \\
\text { that online learning activities help } \\
\text { teachers think innovatively and } \\
\text { creatively, and online learning } \\
\text { activities provide teachers with } \\
\text { computer skills. } \\
\text { Most teachers admit that online } \\
\text { learning reduces social } \\
\text { interaction between teachers and } \\
\text { students, and the learning } \\
\text { process can be disrupted because } \\
\text { of poor accessibility to the } \\
\text { internet connection. }\end{array}$ \\
\hline $\begin{array}{l}\text { Foti } \\
(2020)\end{array}$ & $\begin{array}{l}\text { 1. To describe the main } \\
\text { objectives and conditions } \\
\text { for distance education } \\
\text { and then present the } \\
\text { research in kindergartens } \\
\text { of the 3rd region in } \\
\text { Athens during the closing } \\
\text { period of schools due to } \\
\text { Covid-19. } \\
\text { 2. To explore perceptions, } \\
\text { possibilities, and } \\
\text { limitations regarding the } \\
\text { implementation of } \\
\text { distance learning in } \\
\text { kindergarten schools. }\end{array}$ & $\begin{array}{l}\text { 101 primary } \\
\text { school } \\
\text { teachers } \\
\text { teaching in } \\
\text { kindergarte } \\
\text { ns } \quad(100 \\
\text { female, } 1 \\
\text { male) }\end{array}$ & $\begin{array}{l}\text { Quantitative: } \\
\text { Survey, } \\
\text { Google Form, } \\
\text { electronic } \\
\text { questionnaire, } \\
\text { Part A: } \\
\text { Demographics } \\
\text { Part B: } \\
\text { Recording } \\
\text { possibilities, } \\
\text { safeguards, } \\
\text { and } \\
\text { limitations } \\
\text { regarding } \\
\text { distance } \\
\text { learning. }\end{array}$ & $\begin{array}{l}\text { - } \text { Teachers immediately responded } \\
\text { to the vast majority of them. They } \\
\text { organized distance education in } \\
\text { its asynchronous form to } \\
\text { maintain communication with } \\
\text { their students and respond as } \\
\text { helpers of the Greek family in this } \\
\text { abrupt and sudden situation that } \\
\text { everyone was asked to deal with. } \\
\text { Online social networking } \\
\text { environments that incorporate } \\
\text { many interaction and } \\
\text { communication capabilities can } \\
\text { be a conditional, useful } \\
\text { instrument in distance learning. } \\
\text { Modern distance learning, which } \\
\text { supports the simultaneous } \\
\text { interaction between instructors } \\
\text { and trainees, between students } \\
\text { and teachers, instructors and } \\
\text { trainees can have a voice and } \\
\text { visual communication located in } \\
\text { different places (Mouzakis, 2004). } \\
\text { Teachers assessed it as very } \\
\text { useful in the current situation. } \\
\text { Still, it should be emphasized and } \\
\text { pointed out by the respondents; } \\
\text { it cannot replace live teaching, } \\
\text { promoting active interaction } \\
\text { towards knowledge gain. }\end{array}$ \\
\hline
\end{tabular}




\begin{tabular}{|c|c|c|c|c|c|c|}
\hline $\begin{array}{l}\text { Orhan \& } \\
\text { Beyhan } \\
(2020)\end{array}$ & $\begin{array}{l}\text { 1. RQ: What are the } \\
\text { teachers' perceptions and } \\
\text { teaching experiences on } \\
\text { distancer education } \\
\text { through video } \\
\text { conferencing? }\end{array}$ & 15 teachers & $\begin{array}{l}\text { Qualitative: } \\
\text { Case study } \\
\text { (semi- } \\
\text { structured } \\
\text { interview) }\end{array}$ & 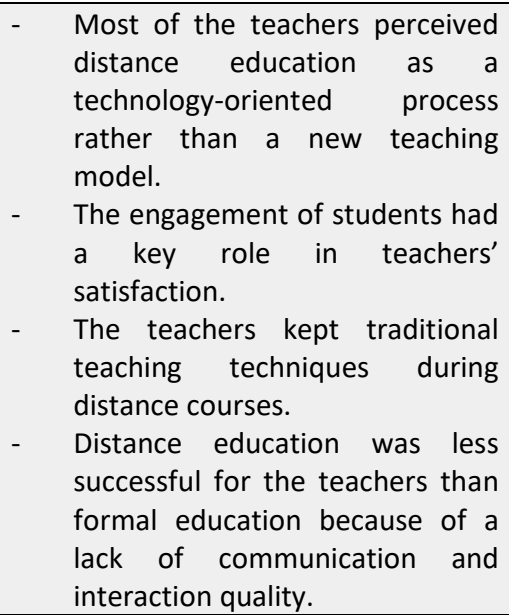 & - & $\begin{array}{l}\text { Perceptions affect } \\
\text { behaviour, and the } \\
\text { quality of distance } \\
\text { education } \\
\text { applications affects } \\
\text { the perceptions. } \\
\text { So, determining } \\
\text { the teachers' } \\
\text { perceptions and } \\
\text { taking the } \\
\text { necessary measures is crucial } \\
\text { to enhancing the } \\
\text { system's quality. }\end{array}$ \\
\hline $\begin{array}{l}\text { Alea, } \\
\text { Fabrea, } \\
\text { Roldan, } \\
\& \\
\text { Farooqi } \\
(2020)\end{array}$ & $\begin{array}{l}\text { 1. Explored teachers' } \\
\text { awareness about the } \\
\text { Covid-19 pandemic and } \\
\text { their opinion on their } \\
\text { respective schools' } \\
\text { readiness and response to } \\
\text { the challenges of } \\
\text { conducting distance } \\
\text { learning education in the } \\
\text { Philippines. }\end{array}$ & $\begin{array}{l}2300 \\
\text { teachers }\end{array}$ & $\begin{array}{l}\text { Quantitative: } \\
\text { An online } \\
\text { questionnaire } \\
\text { (Google Form } \\
\text { Random } \\
\text { sampling) }\end{array}$ & 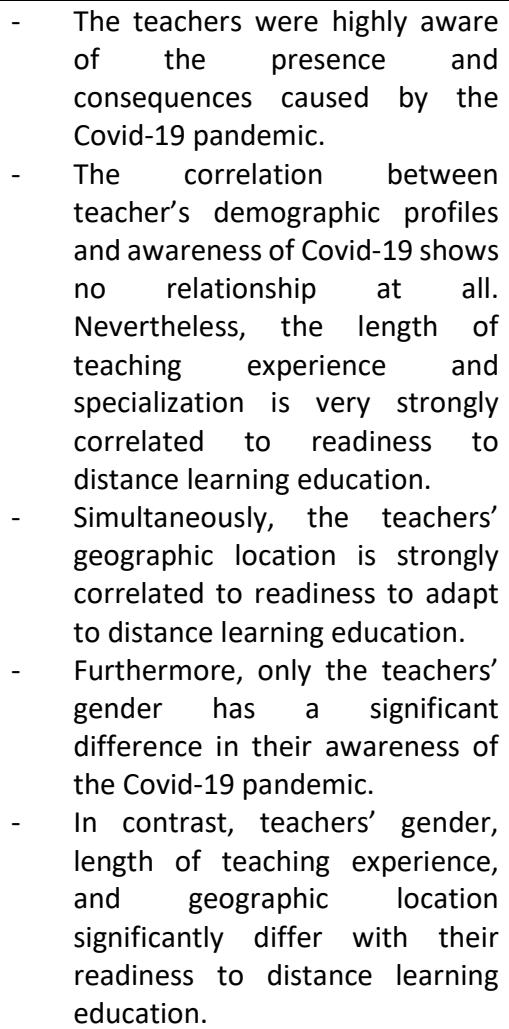 & & $\begin{array}{l}\text { This study can be } \\
\text { used as a basis for } \\
\text { further research, } \\
\text { particularly in } \\
\text { developing } \\
\text { institutional plans } \\
\text { better to } \\
\text { understand the } \\
\text { status of their } \\
\text { teachers and } \\
\text { educational } \\
\text { organizations, and } \\
\text { schools' readiness } \\
\text { to teach and learn } \\
\text { through distance } \\
\text { learning approach; } \\
\text { hence, preserving } \\
\text { and continuing } \\
\text { educational } \\
\text { mission during the } \\
\text { current or future } \\
\text { pandemic as well } \\
\text { as be prepared for } \\
\text { any natural } \\
\text { disasters. }\end{array}$ \\
\hline $\begin{array}{l}\text { Rasmita } \\
\text { dila, } \\
\text { Aliyyah, } \\
\text { Rachma } \\
\text { dtullah, } \\
\text { Samsudi } \\
\text { n, } \\
\text { Syaodih } \\
\text { Nurtant } \\
\text { 0, \& } \\
\text { Tambun } \\
\text { an } \\
\text { (2020) }\end{array}$ & $\begin{array}{l}\text { 1. Explores the } \\
\text { perceptions of primary } \\
\text { school teachers of online } \\
\text { learning in a program } \\
\text { developed in Indonesia } \\
\text { called School from Home } \\
\text { during the Covid-19 } \\
\text { pandemic. }\end{array}$ & $\begin{array}{l}67 \text { class } \\
\text { teachers in } \\
\text { primary } \\
\text { schools. }\end{array}$ & $\begin{array}{l}\text { Surveys and } \\
\text { semi- } \\
\text { structured } \\
\text { interviews } \\
\text { Thematic } \\
\text { analysis for } \\
\text { data: } \\
\text { themes: } \\
\text { instructional } \\
\text { strategies, } \\
\text { challenges, } \\
\text { support, and } \\
\text { motivation of } \\
\text { teachers. }\end{array}$ & $\begin{array}{l}\text { This research contributes to the } \\
\text { literature on online collaborative } \\
\text { learning between teachers, } \\
\text { parents, and schools that impact } \\
\text { student success. Broadly, the } \\
\text { success of online education in } \\
\text { Indonesia during the Covid-19 } \\
\text { pandemic was determined by } \\
\text { technology readiness in line with } \\
\text { the national humanist } \\
\text { curriculum, support and } \\
\text { collaboration from all } \\
\text { stakeholders, including } \\
\text { government, schools, teachers, } \\
\text { parents, and parents of the } \\
\text { community. }\end{array}$ & & $\begin{array}{l}\text { More } \\
\text { comprehensive } \\
\text { and requires } \\
\text { quantitative } \\
\text { studies or mixed- } \\
\text { methods studies. } \\
\text { Could address the } \\
\text { perceptions of } \\
\text { students and } \\
\text { parents about the } \\
\text { implementation of } \\
\text { online learning } \\
\text { during SFH. } \\
\text { It could be } \\
\text { expanded to other } \\
\text { provinces in } \\
\text { Indonesia. } \\
\text { Could examine the } \\
\text { development of } \\
\text { online learning }\end{array}$ \\
\hline
\end{tabular}




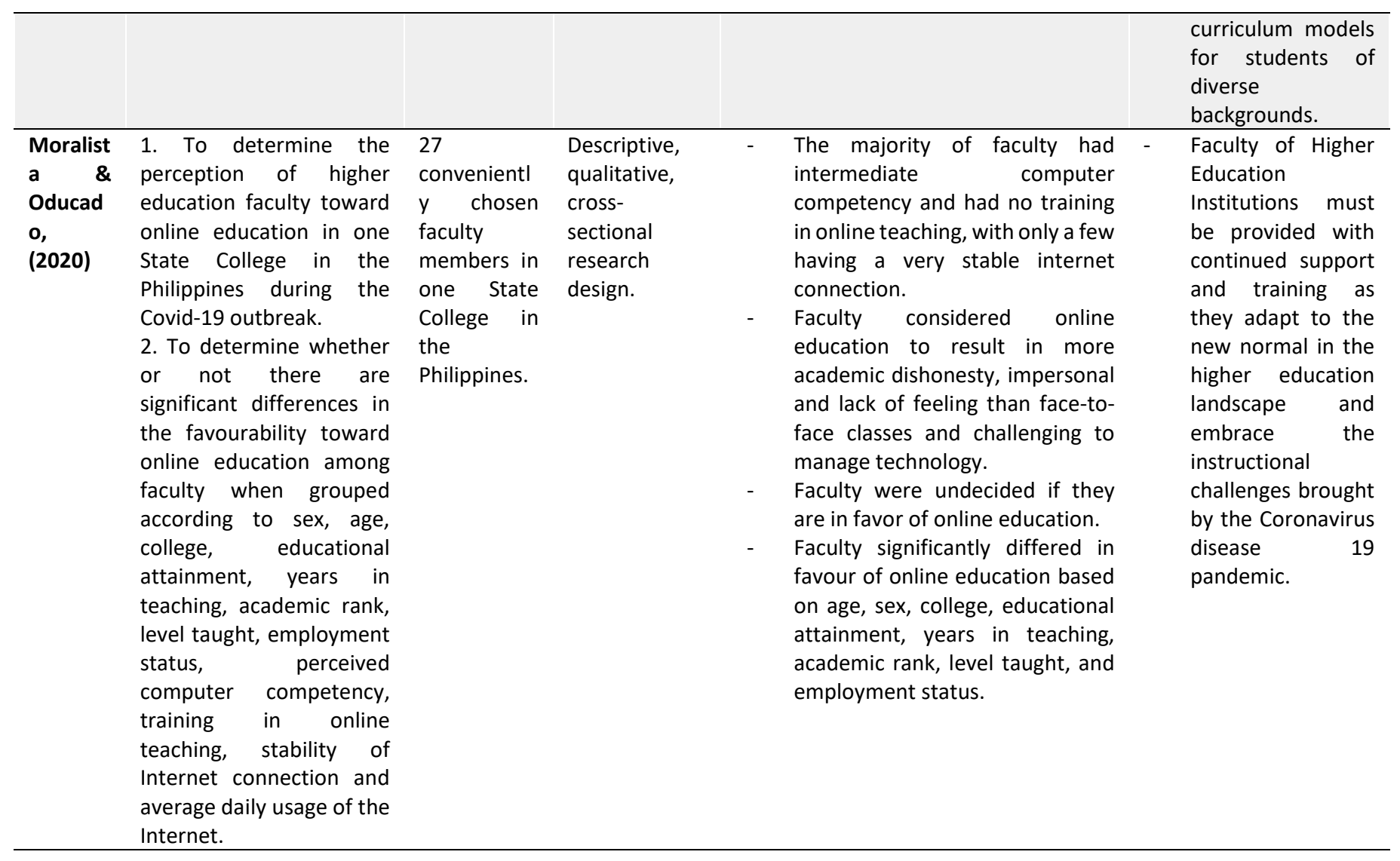

Table 3: Summary of past related studies which focussed on students' perceptions.

\begin{tabular}{|c|c|c|c|c|c|c|}
\hline $\begin{array}{l}\text { Article/ } \\
\text { Study }\end{array}$ & Aim of study & $\begin{array}{l}\text { Number of } \\
\text { participants }\end{array}$ & $\begin{array}{l}\text { Research } \\
\text { design }\end{array}$ & Findings & & $\begin{array}{l}\text { Suggestions/Future } \\
\text { research }\end{array}$ \\
\hline $\begin{array}{l}\text { Syahrin \& } \\
\text { Salih } \\
(2020)\end{array}$ & $\begin{array}{l}\text { 1. To investigate } \\
\text { the online learning } \\
\text { experience of a } \\
\text { group of ESL } \\
\text { students at a } \\
\text { higher learning } \\
\text { institution in Oman } \\
\text { during the Covid- } \\
\text { 19. }\end{array}$ & $\begin{array}{l}32 \\
\text { undergradu } \\
\text { ate students } \\
\text { enrolled in } \\
\text { an ESL } \\
\text { course at } \\
\text { the end of } \\
\text { the Spring } \\
2020 / 21 \\
\text { term }\end{array}$ & $\begin{array}{l}\text { Quantitative } \\
: \quad \text { Online } \\
\text { questionnair } \\
\text { e (Kolb } \\
\text { Learning } \\
\text { Style } \\
\text { Inventory } \\
\text { (1985), } \\
\text { evaluation } \\
\text { of Moodle } \\
\text { technology } \\
\text { in } \quad \text { ESL } \\
\text { course }\end{array}$ & - & $\begin{array}{l}\text { The majority of the students' } \\
\text { preferred learning style is } \\
\text { reflected in the technologies } \\
\text { they experienced in the } \\
\text { online classroom. } \\
\text { The emphasis of the } \\
\text { particular skill-based } \\
\text { pedagogy ESL classroom is } \\
\text { on receptive skills (listening } \\
\text { and reading). }\end{array}$ & $\begin{array}{l}\text { To } \\
\text { document } \\
\text { the } \\
\text { students' } \\
\text { actual } \\
\text { learning } \\
\text { style in an } \\
\text { ESL skill- } \\
\text { based } \\
\text { pedagogy } \\
\text { classroom. }\end{array}$ \\
\hline
\end{tabular}




\begin{tabular}{|c|c|c|c|c|c|}
\hline $\begin{array}{l}\text { Assalahi } \\
\text { (2020) }\end{array}$ & $\begin{array}{l}\text { 1. Investigates } \\
\text { English as a Foreign } \\
\text { Language (EFL) } \\
\text { students' } \\
\text { perceptions of the } \\
\text { causal } \\
\text { relationships } \\
\text { among teaching, } \\
\text { social, and } \\
\text { cognitive } \\
\text { presences, } \\
\text { indicative of a } \\
\text { community of } \\
\text { inquiry in online } \\
\text { EFL courses. Their } \\
\text { relationships to } \\
\text { demographic } \\
\text { variables are also } \\
\text { explored. }\end{array}$ & $\begin{array}{l}737 \quad E F L \\
\text { foundation } \\
\text { year } \\
\text { students } \\
\text { Blackboard } \\
\text { as LMS }\end{array}$ & $\begin{array}{l}\text { Quantitative } \\
\text { Random } \\
\text { sampling } \\
\text { Survey }\end{array}$ & $\begin{array}{l}\text { Results revealed that } \\
\text { teaching presence was the } \\
\text { core factor in sustaining an } \\
\text { online community of inquiry, } \\
\text { and gender significantly } \\
\text { predicted perceptions of } \\
\text { teaching presence. }\end{array}$ & \\
\hline $\begin{array}{l}\text { Eltom } \\
\text { Rahmtall } \\
\text { ah, Enas } \\
\text { \& Al-Saim } \\
\text { (2021) }\end{array}$ & $\begin{array}{l}\text { 1. Elicit student's } \\
\text { perception about } \\
\text { improving } \\
\text { language through } \\
\text { Online Language } \\
\text { Learning Websites } \\
\text { (OLLW) }\end{array}$ & $\begin{array}{l}143 \text { Female } \\
\text { Saudi } \\
\text { students } \\
\text { from College } \\
\text { of Science \& } \\
\text { Arts, Qassim } \\
\text { University }\end{array}$ & $\begin{array}{l}\text { Quantitative } \\
\text { : Structured, } \\
\text { three-part } \\
\text { questionnair } \\
\text { e }\end{array}$ & $\begin{array}{l}\text { 1) Usefulness of OLLW } \\
\text { - Students primarily agree that } \\
\text { OLLWs help improve their } \\
\text { English Language (Authentic } \\
\text { Materials, Ease of access, } \\
\text { variety of expressions \& } \\
\text { vocabulary) } \\
\text { 2) Motivation to use OLLW } \\
\text { Generally, } \\
\text { perception to use OLLWs } \\
\text { (Fun, motivates frequent } \\
\text { practice, encourage self- } \\
\text { study) } \\
\text { 3) Problems \& Difficulties } \\
\text { The main problem is high } \\
\text { subscription fees \& most } \\
\text { OLLWs are paid sites. } \\
\text { Other common problems } \\
\text { (Internet access, difficulty to } \\
\text { get help, need self- } \\
\text { commitment) }\end{array}$ & 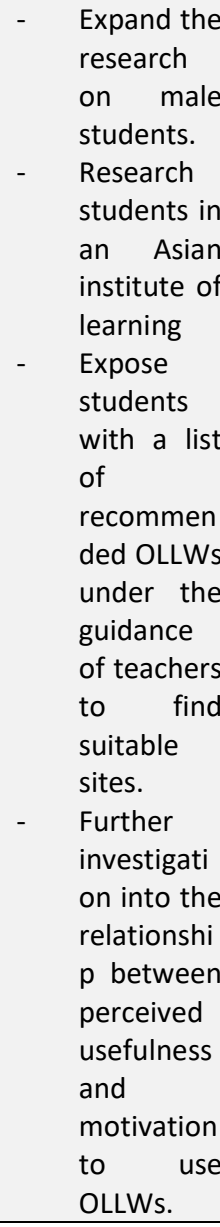 \\
\hline
\end{tabular}




\begin{tabular}{|c|c|c|c|c|c|c|}
\hline $\begin{array}{l}\text { Rakhman } \\
\text { ina, } \\
\text { Martina, } \\
\text { Halolo, } \\
\text { Syafryadi } \\
\text { n \& } \\
\text { Noerman } \\
\text { zah } \\
(2020)\end{array}$ & $\begin{array}{l}\text { 1. Aims to describe } \\
\text { students' } \\
\text { perceptions of } \\
\text { learning English } \\
\text { online during the } \\
\text { Covid-19 } \\
\text { pandemic. }\end{array}$ & $\begin{array}{l}66 \\
\text { undergradu } \\
\text { ates }\end{array}$ & $\begin{array}{l}\text { Quantitative } \\
: \\
\text { questionnair } \\
\text { e, Google } \\
\text { Form }\end{array}$ & $\begin{array}{l}\text { - Most students are interested } \\
\text { in online learning. } \\
\text { Online learning is considered } \\
\text { more fun and flexible. } \\
\text { - WhatsApp is considered the } \\
\text { best application and is very } \\
\text { helpful for online learning } \\
\text { during the pandemic. (Over } \\
\text { Zoom) } \\
\text { Most challenging skill: } \\
\text { listening }\end{array}$ & - & $\begin{array}{l}\text { Better } \\
\text { internet } \\
\text { support } \\
\text { (affordable } \\
\text { ). } \\
\text { Teachers } \\
\text { and } \\
\text { schools } \\
\text { should } \\
\text { respond to } \\
\text { the needs } \\
\text { of students } \\
\text { (lack of } \\
\text { financial } \\
\text { support } \\
\text { and } \\
\text { accessibilit } \\
\text { y of the } \\
\text { Internet). }\end{array}$ \\
\hline $\begin{array}{l}\text { Hazayme } \\
\text { h (2021) }\end{array}$ & $\begin{array}{l}\text { 1. The study aimed } \\
\text { to investigate } \\
\text { participants' } \\
\text { perceptions of } \\
\text { online distance } \\
\text { learning during the } \\
\text { Covid-19 pandemic } \\
\text { for empowering } \\
\text { them to achieve } \\
\text { ISTE standards } \\
\text { within the EFL } \\
\text { classroom. }\end{array}$ & $\begin{array}{l}60 \\
\text { undergradu } \\
\text { ate students } \\
\text { participated } \\
\text { in this study } \\
\text { by } \\
\text { responding } \\
\text { to a } \\
\text { designed } \\
\text { online } \\
\text { survey } \\
\text { based on } \\
\text { ISTE } \\
\text { standards }\end{array}$ & $\begin{array}{l}\text { Quantitative } \\
: \quad \text { Online } \\
\text { survey } \\
\text { based on } \\
\text { ISTE } \\
\text { standards }\end{array}$ & 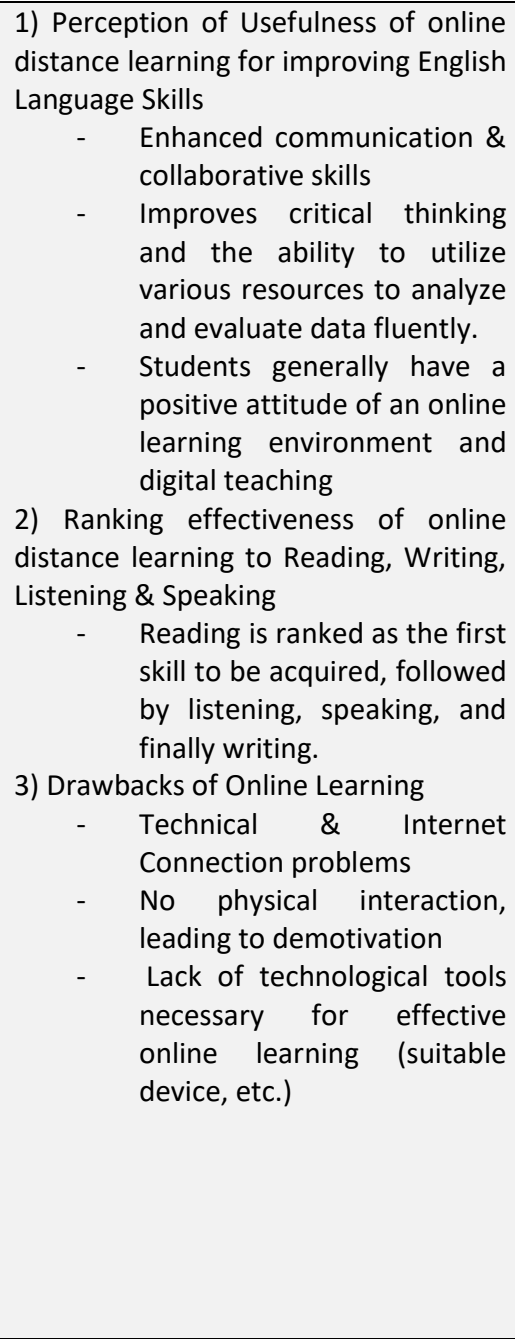 & - & $\begin{array}{l}\text { Focus the } \\
\text { research } \\
\text { towards } \\
\text { each } \\
\text { specific ELS } \\
\text { on } \\
\text { evaluating } \\
\text { what other } \\
\text { methods } \\
\text { can further } \\
\text { enhance } \\
\text { students' } \\
\text { online } \\
\text { learning } \\
\text { experience } \\
\text { Survey } \\
\text { students of } \\
\text { a different } \\
\text { year, } \\
\text { perhaps } \\
\text { more } \\
\text { senior } \\
\text { students } \\
\text { with more } \\
\text { experience } \\
\text { with F2F } \\
\text { classes. } \\
\text { Survey } \\
\text { non- } \\
\text { traditional } \\
\text { students, } \\
\text { like } \\
\text { workers. }\end{array}$ \\
\hline $\begin{array}{l}\text { Ag- } \\
\text { Ahmad } \\
(2020)\end{array}$ & $\begin{array}{l}\text { 1. The purpose of } \\
\text { this study is to } \\
\text { describe the ODL } \\
\text { experiences of } \\
\text { tertiary students, } \\
\text { particularly their } \\
\text { preferences, their } \\
\text { views of the } \\
\text { instructional }\end{array}$ & $\begin{array}{l}68 \\
\text { undergradu } \\
\text { ates from } \\
\text { degree and } \\
\text { diploma } \\
\text { programme } \\
\mathrm{s} \\
48 \text { female, } \\
20 \text { male }\end{array}$ & $\begin{array}{l}\text { Mixed } \\
\text { method: } \\
1 . \\
\text { Questionnai } \\
\text { re } \\
2 . \quad \text { Open- } \\
\text { ended } \\
\text { questions }\end{array}$ & $\begin{array}{l}\text { Aside from connectivity } \\
\text { problems, most students } \\
\text { found that online learning } \\
\text { was difficult for them } \\
\text { because they had many } \\
\text { distractions at home, which } \\
\text { affected their focus and } \\
\text { understanding of the } \\
\text { lessons. }\end{array}$ & & \\
\hline
\end{tabular}


technology, as well

as the issues that

arise in the

integration of their

courses in the new

online class

structure.

\begin{abstract}
It can be concluded that
most of the students perceived that Malaysian institutions and students are partially ready for ODL, and more time is needed to adapt to the new changes, which require empathy, creativity, and a great deal of effort.

- The students also need full support from parents and instructors as empathy and compassion are crucial in this crisis.

- Students need to be given personal space and time to focus on online learning entirely and at the same time be tolerated by lecturers if they need more time, materials, and guidance to complete their tasks.
\end{abstract}

\begin{tabular}{|c|c|c|c|c|c|c|}
\hline $\begin{array}{l}\text { Simanjun } \\
\text { tak, } \\
\text { Silalahi, } \\
\text { Sihombin } \\
\text { g \& Purba } \\
\text { (2021) }\end{array}$ & $\begin{array}{l}\text { 1. To analyze the } \\
\text { students' } \\
\text { perceptions in } \\
\text { using YouTube as } \\
\text { online English } \\
\text { learning media } \\
\text { during the Covid- } \\
19 \text { pandemic at } \\
\text { grade XI of SMA } \\
\text { Negeri } \\
\text { Pematangsiantar. }\end{array}$ & 72 students & $\begin{array}{l}\text { Quantitative } \\
: \quad \text { Google } \\
\text { Form } \\
\text { questionnair } \\
\text { e }\end{array}$ & $\begin{array}{l}\text { 1) Attractiveness } \\
\text { - } \text { Youtube is an interesting } \\
\text { media to facilitate student } \\
\text { interest to learn, especially } \\
\text { the availability of various } \\
\text { videos designed to improve } \\
\text { student language skills } \\
\text { (speaking, performance, } \\
\text { listening). } \\
\text { 2) Effectiveness } \\
\text { Youtube videos are easy to } \\
\text { access and can retain } \\
\text { students' attention } \\
\text { 3) Relevance } \\
\text { Content of videos are easy to } \\
\text { absorb and relevant to } \\
\text { course content } \\
\text { 4) Motivation and and } \\
\text { Youtube media fosters } \\
\text { participation, encourages } \\
\text { more learning, and } \\
\text { motivates studying English } \\
\text { well }\end{array}$ & - & $\begin{array}{l}\text { Repeat the } \\
\text { research } \\
\text { using } \\
\text { another } \\
\text { social } \\
\text { media to } \\
\text { compare } \\
\text { the } \\
\text { effectivene } \\
\text { ss (TikTok, } \\
\text { Instagram, } \\
\text { Twitter, } \\
\text { etc.). } \\
\text { Compare } \\
\text { the type of } \\
\text { Youtube } \\
\text { videos' } \\
\text { effectivene } \\
\text { ss (Musical } \\
\text { vs. } \\
\text { document } \\
\text { ary vs. } \\
\text { instruction } \\
\text { al, etc.). } \\
\text { Conduct } \\
\text { on } \\
\text { different } \\
\text { age groups } \\
\text { of } \\
\text { students. }\end{array}$ \\
\hline $\begin{array}{l}\text { Haleman } \\
\& \text { Yamat } \\
(2021)\end{array}$ & $\begin{array}{l}\text { 1. To investigate } \\
\text { the perception } \\
\text { towards e-learning } \\
\text { among ESL primary } \\
\text { school students. } \\
2 . \text { To determine } \\
\text { the level of } \\
\text { students' } \\
\text { acceptance }\end{array}$ & $\begin{array}{l}100 \text { upper } \\
\text { primary } \\
\text { school } \\
\text { students in } \\
\text { Sibu, } \\
\text { Sarawak. }\end{array}$ & $\begin{array}{l}\text { Quantitative } \\
\text { : } \\
\text { Questionnai } \\
\text { re }\end{array}$ & $\begin{array}{l}\text { The results revealed that the } \\
\text { perception of e-learning was } \\
\text { positive. The level of e- } \\
\text { learning acceptance among } \\
\text { ESL primary school students } \\
\text { was high due to its features } \\
\text { of e-learning, such as } \\
\text { flexibility, user-friendliness, } \\
\text { and the students' attitude }\end{array}$ & - & $\begin{array}{l}\text { It was } \\
\text { recommen } \\
\text { ded that } \\
\text { teachers } \\
\text { utilize } \\
\text { student- } \\
\text { friendly } \\
\text { digital } \\
\text { tools to } \\
\text { deliver }\end{array}$ \\
\hline
\end{tabular}




\begin{tabular}{|c|c|c|c|c|c|}
\hline & $\begin{array}{l}\text { towards } \\
\text { learning. }\end{array}$ & & & $\begin{array}{l}\text { towards using and the } \\
\text { intention to use in the future. }\end{array}$ & $\begin{array}{l}\text { their } \\
\text { teaching } \\
\text { and } \\
\text { learning } \\
\text { materials } \\
\text { so that the } \\
\text { students, } \\
\text { especially } \\
\text { at the } \\
\text { primary } \\
\text { level, find } \\
\text { it easy and } \\
\text { enjoy } \\
\text { learning } \\
\text { English via } \\
\text { e-learning. }\end{array}$ \\
\hline $\begin{array}{l}\text { Sevy- } \\
\text { Biloon } \\
\text { (2021) }\end{array}$ & $\begin{array}{l}\text { 1. This study looks } \\
\text { at the pros and } \\
\text { cons of both virtual } \\
\text { and face-to-face } \\
\text { classrooms from } \\
\text { the students' } \\
\text { perception. }\end{array}$ & $\begin{array}{l}69 \text { upper } \\
\text { intermediat } \\
\text { e ELT } \\
\text { teacher } \\
\text { trainee } \\
\text { students }\end{array}$ & $\begin{array}{l}\text { Qualitative: } \\
1 . \quad \text { Online } \\
\text { questionnair } \\
\text { e: } \\
\text { structured } \\
\text { and open- } \\
\text { ended } \\
\text { questions. } \\
2 . \\
\text { Observation } \\
\text { from virtual } \\
\text { meetings } \\
3 . \quad \text { One-on- } \\
\text { one } \\
\text { interview }\end{array}$ & $\begin{array}{l}\text { - Some prefer online learning } \\
\text { for various reasons such as } \\
\text { safety, comfort, economic } \\
\text { reasons, and more available } \\
\text { time. } \\
\text { Some find E-learning difficult } \\
\text { and want to return to } \\
\text { synchronous classes because } \\
\text { they feel little interaction } \\
\text { between classmates and } \\
\text { teachers. They cannot } \\
\text { practice English } \\
\text { authentically, cannot get } \\
\text { clarification from the } \\
\text { teacher, have a hard time } \\
\text { concentrating online there } \\
\text { are constant internet } \\
\text { connection issues. }\end{array}$ & \\
\hline
\end{tabular}

\section{Perceptions on Distance Learning - Teachers' \& Students' Perspective}

Table 1 explores the five past studies on teachers' and students' perceptions of distance learning during the Covid-19 pandemic. While both sides understand the necessity of transitioning towards distance learning in these troubled times, the abrupt pace at which the roll-out was conducted has uncovered surprising perceptions in the researchers' respective studies, both positive and negative.

\section{Positive Perceptions by Teachers and Students}

Niemi \& Kousa (2020) found in their study that both teachers and students generally have positive perceptions of the benefits of distance learning. This result corroborates with the findings of Hebebci et al. (2020), who further expand on the various overlapping advantages highlighted by teachers and students, such as having shorter, concise classes, ease of access, and fostering continued education.

Utilizing the various online communications tools available today, such as Youtube, Google Classroom, and Zoom, teachers and students alike agree that they now have more opportunities to carry out collaborative work despite being physically apart as well as continue the overall learning autonomy of students while improving communication skills (Aldossary, 2021). Aldossary (2021) further elaborates that having access to using the various multimedia channels also provides appropriate course content delivery, which is also easily accessible for students. 


\section{Negative Perceptions by Teachers and Students}

Despite the apparent benefits of e-learning, both teachers and students experienced various hiccups from the initial implementation of e-learning until the prolonged application to this day. Teachers found that the overall lesson process has become disrupted due to insufficient time as well as the drop in student interaction which in turn also made it hard for students to understand their lessons (Hebebci et al., 2020). Silva and Sousa's (2020) study found that teachers had a more positive outlook than students, where the students did not find the transition to be motivating or easy. This is possibly compounded by other correlating factors such as lack of engaging activities, low social relationships between peers, and the gap between teachers' provided work and students feeling overloaded with work (Niemi and Kousa, 2020). It is worth noting that some students still show a higher level of preference for face-to-face lessons compared to distance learning in Niemi and Kousa's (2020) study.

All five studies have highlighted those technological issues such as poor connectivity and obsolescence of devices have affected teachers' and students' perception at some point, with Churiyah (2020) noting that teachers also stutter in the face of the urgent need to embrace IT literacy to facilitate teaching. This is an arduous task for the older generations of teachers who may not be sufficiently IT savvy and would cause negative perception for both the teacher teaching and the student learning.

\section{Neutral Perception by Teachers and Students}

The participants in Aldossary's (2021) study had a neutral view of the general use of eLearning platforms during the Covid-19 pandemic for studies. Both teachers and students did not have any particular preference or dislike of distance learning, understanding that the shift was a necessary endeavour to facilitate the continuation of education as a whole. There were technological challenges in pursuing distance learning, but no central element threw off teachers or students alike from further online learning (Aldossary, 2021).

\section{Perceptions on Distance Learning - Teachers' Perspectives}

Teachers play an essential role in education institutions. Literature informs us that teachers are those who have the ability to "encourage colleagues to change" (Wasley, 1991, p. 23) and have the willingness to "lead beyond the classroom and contribute to the community of students" (Katzenmeyer \& Moller, 2001, p. 17). Therefore, it is crucial to gather and investigate teachers' perspectives towards the current implementation of distance learning. Table 2 summarizes 8 studies that examined teachers' perspectives towards distance learning during the pandemic. The findings can be discussed in several themes, including technological, social, and pedagogical factors. The positive perceptions of teachers will be first discussed in the themes mentioned, followed by negative perspectives.

\section{Positive Perceptions from Studies about Teachers}

Teachers are themselves students who constantly seek to improve on themselves for the betterment of their students. Even before the time of the pandemic, the need for upskilling and professional development has never been exhaustive (Omar \& Hashim, 2021). It is also stated that the respondents' relatively high scores of perceived usefulness state a more open perception of embracing current instructional technologies and educational trends on top of their conventional teaching routine and methods. It is, therefore, unsurprising that Nusalina \& Fitrawati (2021) found that most teachers have positive perceptions about online learning 
media. The study also reveals that teachers acknowledge that online learning activities assist them in thinking innovatively and imaginatively, compensating for their lack of computer abilities.

The closing of schools affected by Covid-19 has brought unprecedented difficulties to the education field. In order to continue the educational activity and the overall pedagogical process, new data and obstacles emerged, and the usage of electronic means of communication in teaching and learning was unavoidable. This is especially true for education dealing with younger students. Kindergarten instructors, in particular, were required to answer to even more severe obstacles and difficulties in the field of pre-school education, taking into account the children's age (4-6 years) and their objective inability to approach computerized forms of instruction (Foti, 2020). However, in the study in Greece, teachers pointed out that distance learning technology that allowed them to organize asynchronous lessons to maintain communication with their students and respond to their parents was helpful in the current situation, although it cannot replace it live teaching.

The findings are similar to a qualitative study in Romania by Orhan and Beyhan (2020) on primary and secondary school teachers. The participants of the studies responded that they could react to distance learning as they viewed distance education as a technology-oriented adaptive process to aid teaching and learning rather than a new pedagogy. The study also mentioned that student engagement played a vital role in teachers' satisfaction and motivation. The instance of responsive and engaging lessons or would promote more interactive pedagogy by the teacher. Nevertheless, teachers who view distance learning as a useful tool or an opportunity for the continuation of education during lockdown would lead to a more positive acceptance of using distance learning tools in their lessons (Omar \& Hashim, 2021; Nursalina \& Fitrawati, 2021; Foti, 2020; Orhan \& Beyhan, 2020; Alea et al., 2020).

Another factor contributing to teachers' positive perception of distance learning during the pandemic is school authority, local government, and student parents. Rasmitadila et al. (2020) show that a flexible national curriculum, technological support, and collaboration are critical to successful online learning. Not only teachers and students should know about the usage of online learning platforms, but parents and the wider community as well. The availability of an online platform for government public schools nationwide would ease teachers' burden and educate the public about the use of such platforms so that that distance education can be benefited by all (Yew \& Tan, 2020; Rasmitadila et al., 2020; Omar \& Hashim, 2021).

\section{Negative Perceptions from Studies about Teachers}

Neither teachers nor students were prepared for total distance education to replace the usual face-to-face interaction when the pandemic hit. The irreversible disruption to the current education curriculum was unforeseen and unprecedented. Due to this, many teachers have negative perceptions towards distance learning during the pandemic even though they have taken up the responsibilities to implement distance learning in the tough times of lockdowns during the pandemic. One of the main reasons is that teachers found distance learning less interactive as compared to face-to-face- teaching (Foti, 2020; Orhan \& Beyhan, 2020, Nusalina \& Fitrawati, 2021). There's a gap between the intended teaching outcomes and the actual products of lessons, as distance learning lacks communication and has a poorer interaction quality (Orhan \& Beyhan, 2020). The study also points out that the readiness of teachers and students to adopt distance learning is the key to improve distance education quality. On the 
other hand, Foti (2020) mentions that although teachers agree that distance learning is helpful in the current situation, it cannot replace live teaching, which allows for instant and authentic interaction between teachers and students for knowledge gain.

Another main reason teachers have negative perceptions towards distance learning is due to technological factors. The absence of infrastructure was one of the critical factors preventing teachers from using online instructional tools. The participants had sufficient access to the infrastructure and online resources required to conduct online instruction (Yew \& Tan, 2020). Moralista and Oducado (2020) stated in the study that the majority of the teaching faculty had only intermediate ICT competency with no prior training on online teaching before the pandemic, which contributed to a lot of difficulties and challenges in conducting distance education. Furthermore, the study revealed that only a few of the teaching members had a stable internet connection when they were supposed to be rigorously adapting to online teaching.

Since teachers usually work in educational institutions, be it at the primary, the secondary, or tertiary level at fixed working hours, they had to adapt to working from home. Yew \& Tan (2020) mentioned that teachers are often distracted from focussing on their work by household chores, family obligations, and other responsibilities which arise due to lockdowns during the pandemic. Alea et al. (2020) agreed that such distractions and responsibilities affected work performance and created more stress for teachers working from home. Finally, Moralista \& Oducado (2020) suggested in the study that many teachers see that there is a high potential for misuse of technological tools, especially in online assessment. The study states that online education, according to faculty, leads to increased academic dishonesty, is impersonal and lacks empathy when compared to face-to-face classes, and is challenging to manage technologically.

\section{Perceptions on Distance Learning - Students' Perspective}

Students in the current Covid-19 pandemic are going through an unprecedented situation unlike at any time ever recorded. Never before in history has formal education been equipped with sufficient tools to be disseminated despite the inability to conduct face-to-face lessons. As such, data on the current perception of students towards distance learning is vital to key policymakers and stakeholders as a gauge to which plans in the event of another pandemic can be made. Beyond that, understanding student perceptions will also help current educators adapt and restructure their teaching methodologies and materials to provide a practical learning experience. Table 3 shows an interesting mix of perceptions from the students, with findings from researchers unearthing concurrent positive and negative views within the same group of students.

\section{Positive Perception by Students}

Beyond the core reason of implementing distance learning to combat the spread of Covid-19, another essential benefit to note for e-learning would be the sheer level of appeal and potential entertainment value that can be brought into lessons. Students can be regaled with learning materials in various types of media, be it audiobooks, videos, and even educational games. For example, gamification of language exercises on online language learning websites (OLLWs) makes the lessons fun, motivates frequent practice, and encourages students to selfstudy (Eltom Rahmatallah \& Al-Saim, 2021). Youtube is also another vital source of exciting media to facilitate students' interest in learning. There are now entire channels by educators 
and subject experts dedicated to producing educational content. The availability of videos designed to educate viewers and even improve soft skills such as speaking, and listening can be found on Youtube. This makes online learning a more enjoyable and flexible learning experience for students (Rakhmanina et al., 2020; Simanjuntak et al., 2021).

The Internet has also opened up another often-overlooked benefit; the ease of accessibility to study materials. Students in today's world are so often connected online that they have never indeed had to experience a time when learning was not at the tip of their fingertips. Thanks to e-learning, materials can be revisited at any time since most are stored in an online server, and teachers are often the gatekeepers to ensure the quality of the classroom materials (Eltom Rahmtallah \& Al-Saim, 2021). Past lessons viewed on Youtube can be paused, rewind, and even fully replayed as often as the students like at their own pace and preferred learning style (Simanjuntak et al., 2021; Syahrin \& Salih, 2020). Today's online sites have also been streamlined to be as flexible and user-friendly as possible to cater to every user, so the level of distance learning acceptance, especially among the younger generation, is high (Haleman \& Yamat, 2021). Sevy-Biloon (2021) points out that the current generation of students is comfortable with embracing online learning and takes less time to pick up their lessons, seeing as the learning curve to using distance learning technology is less steep.

\section{Negative Perceptions from Studies by Students}

With the sudden shift from conventional classrooms to distance learning, the requirements to have a conducive learning experience have also evolved. Unlike being in a physical classroom, where enthusiastic students can move towards the front of the class to sit closer to their teachers or raise their hand for clarification, students are now restricted by a combination of physical distance as well as technological limitations. Assalahi (2020) 's study revealed that a teacher's presence was a core factor in sustaining an interactive learning environment of inquiry. This result is also reflected in the studies of other researchers, such as Hazaymeh (2021), whose student respondents reported feelings of demotivation due to a lack of physical interaction and Sevy-Biloon (2021), where the students who are not able to practice their English lesson authentically began having a more challenging time concentrating online. When it becomes difficult to get help, students start to lose their initial levels of self-commitment to studies, leading to a loss in concentration (Eltom Rahmtallah \& Al-Saim, 2021). Not every student is blessed with a conducive study environment at home as well, where distractions such as chores and home comforts may corrode student focus and affect the understanding of their lessons (Ag-Ahmad, 2020).

Another critical matter to consider is the lack of financial support in the transition towards distance learning. This causes a two-pronged issue, which both stems from financial constraints; paid services and technological tools. As more and more content is being created for online learning, most of the higher quality materials are now kept behind paywalls and subscription fees ((Rahmtallah \& Al-Saim, 2021). This is especially true for established online learning websites that price their offerings at premium rates for access to services or exercises. This severely hampers students who come from middle to lower-income families who may not be able to afford additional expenditures beyond their day-to-day necessities, especially during the pandemic where livelihoods have been severely impacted.

Then technological tools come in as another element to consider. This is a combination of both the quality of the devices available to the student and the strength of the internet connectivity. Hazaymeh (2021) highlights that lacking a suitable device, be it a computer or a 
smartphone, and a stable internet connection hampers the effectiveness of online learning. Each research evaluated in this study has pinpointed internet connection issues as a factor that negatively affected student perception over distance learning. Students in urban areas tend to be less affected by internet connectivity issues. Still, those whose homes are located outside the adequate coverage of the internet service providers (ISP) will undergo additional difficulty to participate in their online classes. This will range from joining the class, getting their study materials to being able to submit homework on time.

\section{Conclusion}

This systematic literature review analysed both students and teachers' perception towards distance learning during the Covid-19 pandemic. Their perspectives were analysed from the positive and negative views about distance learning during the Covid-19 pandemic. Recurring themes identified in the studies showed results of having varied perspectives towards distance learning due to various factors such as social, technological, and pedagogical factors. The findings also revealed that teachers and students lack experience which influenced their perceptions of distance education and had minimal or no readiness to face distance learning during the pandemic. It was also discovered that the teachers saw online education as a supplement to formal education rather than a new teaching approach. It was critical for students to be engaged in order for teachers to be satisfied with remote education. Furthermore, teachers' expectations, difficulties preparing and presenting materials in their fields, and being accustomed to face-to-face education may have influenced their perceptions of distance education. In order to carry out the distance education process effectively and efficiently, it is necessary to define instructor perspectives (Dooley \& Murphrey, 2000).

At the same time, teachers and students alike still found the benefits of distance learning to be worth embracing, especially since the continuation of education could still be upheld with minimal exposure towards Covid-19. The prolonged duration of the pandemic has also opened up new areas of development for e-learning tools, such as better user interfaces for Zoom to facilitate an online classroom, more gamified online learning websites to attract student attention, and also allowing for content creators to innovate better media for teaching viewers on particular subject matters (Simanjuntak et al., 2021). Having the freedom to choose to review their subjects when they feel most motivated rather than restricting students to fixed schedules has helped spur self-motivated students towards a more autonomous learning habit, which will benefit them at later points of their lives. Teachers who have embraced e-learning are exploring the various capabilities of having a system to help automate specific tasks. Homework and learning exercises can now be scheduled to be released at a later time, while assignments to be handed in can be monitored and tabulated. Teachers can easily store all their students' work in a database for easy access while students can track their progress.

As a final result, based on the review of all the articles, the factor that most contributed to teachers' and students' perception towards distance learning during the pandemic should be the level of engagement of the teachers in their attempts to reach out to their students across the distance learning divide. Teachers who have successfully engaged their classes to report better interactions, more effective use of time to convey lessons, and more students participating in group discussions. As students become more invested in their studies, teachers would feel more motivated to embrace distance learning. 


\section{Challenges and Limitations}

There were certain limitations in this study that should be addressed in the future if there are scholars interested in delving deeper into this topic. This study only reviewed 22 articles from five bibliographic databases, namely Google Scholar, Science Direct, ProQuest Education Journal, Educational Resources Information Centre (ERIC), and SAGE Journals. Due to time constraints, articles from other databases like SCOPUS, Springer e-journals, JSTOR, and WoS were not filtered and selected for this systematic review. It would be helpful to expand the research to include more insights from diverse scholars, as the results could either confirm or contradict the findings of this study. Another constraint of this study is that no correspondence was made between the author and the researchers of the selected articles to elicit a more in-depth understanding of the perceptions of the teachers and students towards distance learning during the time of the Covid-19 pandemic. Similar to the first limitation, time restrictions prevented the author of this study from communicating with the researchers personally before reaching a more sound conclusion. Whether in e-mail or video call correspondence, meeting the writers might provide a more in-depth inquiry to shed more light on this review.

\section{Implications and Recommendations for Future Research and Practice}

Based on the systematic literature review conducted, it is evident that very limited studies were done on primary school students. Acknowledging that building a good foundation is essential to equip students to excel in the future, more research should look into this level of education to acquire the primary school students' perception to improve on the current distance learning curriculum. It is also surprising that not many studies were done to investigate both perspectives of the students and teachers at the tertiary level. It would be great to look deeper into this aspect, especially on specific courses or faculties, so that educational policymakers can gather valuable and relevant data to improve the curriculum. Finally, educators and researchers alike should bear in mind that distance learning can be hampered by a lack of ICT skills among students and teachers and a problem with internet connectivity. Educational policymakers and key stakeholders ought to look into each and every issue in-depth and keep finding innovative and practical solutions to benefit the current generation of teachers and students who are 'stuck' in distance learning.

\section{References}

Abdul Halim, A. (2020). COVID-19 Buka Mata Warga Pendidik, Pelajar. Retrieved from: https://www.bharian.com.my/rencana/komentar/2020/03/670374/covid-19-bukamata-warga-pendidik-pelajar

Ag-Ahmad, N. (2020). Open and Distance Learning (ODL): Preferences, Issues and Challenges amidst Covid-19 Pandemic. Journal of Creative Practices in Language Learning and Teaching (CPLT), 8(2).

Alea, L. A., Fabrea, M. F., Roldan, R. D., \& Farooqi, A. Z. (2020). Teachers' Covid-19 Awareness, Distance Learning Education Experiences and Perceptions towards Institutional Readiness and Challenges. International Journal of Learning, Teaching and Educational Research Vol. 19, No. 6, 127-144.

Aldossary, K. (2021). Online Distance Learning for Translation Subjects: Tertiary Level Instructors' and Students' Perceptions In Saudi Arabia. Turkish Online Journal of Distance Education, 22(3), 95-109. 
Al-Hosan, A. M., Rajeh, N. M., \& Hamza, A. (2020). Teachers' perceptions of their role in cognitive awareness, health protection and the promotion of ethical value aspects among students with the Corona Corvid 19 virus pandemic via the distance learning system. Multicultural Education, Volume 6, Issue 5.

Ali, S., Uppal, M. A., \& Gulliver, S. R. (2018). A conceptual framework highlighting e-learning implementation barriers. Information Technology \& People.

Allam, S. N. S., Hassan, M. S., Mohideen, R. S., Ramlan, A. F., \& Kamal, R. M. (2020). Online Distance Learning Readiness During Covid-19 Outbreak Among Undergraduate Students. International Journal of Academic Research in Business and Social Sciences, 10(5), 642-657.

Amir, R. F., Otaki, F., Baqain, Z., Zary, N., Al-Halabi, M. (2021) Rapid transition to distance learning due to COVID-19: Perceptions of postgraduate dental students and instructors. PLOS ONE 16(2): e0246584.

Anderson, T. (2011). Towards a theory of online learning. In The theory and practice of online learning. AU Press-Digital Publications. Retrieved from:

https://read.aupress.ca/read/the-theory-and-practice-of-onlinelearning/section/4d56145b-d99a-474d-9bcb-de69f3683622\#ch02

Ariyanti, A. (2020). EFL Students' Challenges towards Home Learning Policy during COVID-19 Outbreak. Indonesian Journal of English Language Teaching and Applied Linguistics, 5, 167-175.

Assalahi, H. (2020). Learning EFL online during a pandemic: Insights into the quality of emergency online education. International Journal of Learning, Teaching and Education Research 19(11), 203-222.

Brown, C. L. (2015). Secondary Teachers' Perceptions of Online Learning. 107-108.

Carlson, E. R. (2020). COVID-19 and educational engagement. Journal of Oral and Maxillofacial Surgery, 78(7), 1049-1051.

Chan, D., Karim, K. N., \& Yusof, T. A. (2020). Almost 40 Pct Of Students Can't Study At Home As They Lack Electronic Devices. New Straits Times. Retrieved from: https://www.nst.com.my/news/nation/2020/04/584641/almost-40pct-studentscant-study-home-they-lack-electronic-devices

Churiyah, M., Shollikhan, S., Filianti, F., \& Sakdiyyah, D. A. (2020). Indonesia Education Readiness Conducting Distance Learning in Covid-19 Pandemic Situation. International Journal of Multicultural and Multireligious Understanding Volume 7, Issue 6, 491-507.

Clancy, D. S., \& Sentance, M. (2020). Keeping Students Academically Engaged during the Coronavirus Crisis--Part One. Policy Brief. Pioneer Institute for Public Policy Research.

Clark, R. C., \& Mayer, R. E. (2016). E-learning and the science of instruction: Proven guidelines for consumers and designers of multimedia learning. John Wiley \& Sons.

Clouder, L., Dalley, J., Hargreaves, J., Parkes, S., Sellars, J., \& Toms, J. (2006). Electronic [re]constitution of groups: Group dynamics from face-to-face to an online setting. International Journal of Computer-Supported Collaborative Learning, 1(4), 467-480.

Coman, C., Tiru, L. G., Meseasan-Schmitz, L., Stanciu C., and Bularca, M. C. (2020). Online Teaching and Learning in Higher Education during the Coronavirus Pandemic: Students' Perspective. Sustainability, 12, 10367.

Dooley, K. E., \& Murphrey, T. P. (2000). How the perspectives of administrators, faculty, and support units impact the rate of distance education adoption. Online journal of distance learning administration, 3(4). 
Doucet, A., Netolicky, D., Timmers, K., \& Tuscano, F. J. (2020). Thinking about Pedagogy in an Unfolding Pandemic: An Independent Report on Approaches to Distance Learning During COVID 19 School Closures (Vol. 2).

Rahmtallah, E., \& Al-Saim, A. (2021). Efl Students' Perception Of Using Online Language Learning Websites During Covid-19 Pandemic. International Journal of Applied Linguistics. 9. 5-14.

Falloon, G. (2011). Making The Connection: Moore's Theory Of Transactional Distance And Its Relevance To The Use Of A Virtual Classroom In Postgraduate Online Teacher Education. Journal of Research on Technology in Education, 43(3), 187-209

Fauzi, I., \& Khusuma, I. H. (2020). Teachers' Elementary School in Online Learning of COVID19 Pandemic Conditions. Jurnal Iqra': Kajian IImu Pendidikan 5(1), 58-70.

Foti, P. (2020). Research in Distance Learning in Greek Kindergarden Schools During the Pandemic of Covid-19: Possibilities, Dilemmas, Limitations. European Journal of Open Education and E-Learning Studies Volume 5, Issue 1.

Gewin, V. (2020). Five tips for moving teaching online as COVID-19 takes hold. Nature, 580(7802), 295-296.

Giovannella, C., Passarelli, M., \& Persico, D. (2020). Measuring the Effect of the Covid-19 Pandemic on the Italian Learning Ecosystems at the Steady State: A School Teachers' Perspective. Italy.

Haleman, K. N., \& Yaman, H. (2021). The Acceptance of E-Learning Among ESL Primary School Students During COVID-19. Journal of English Language Teaching and Applied Linguistics, 3(1), 08-18.

Hazaymeh, W. A. (2021). EFL students' perceptions of online distance learning for enhancing English language learning during covid-19 pandemic. International Journal of Instruction, 14(3), 501-518.

Hebebci, M. T., Bertiz, Y., \& Alan, S. (2020). Investigation of views of students and teachers on distance education practices during the Coronavirus (COVID-19) Pandemic. International Journal of Technology in Education and Science (IJTES), 4(4), 267-282.

Huang, M. (2021). A Case Study of ESL Students' Remote Speaking Class Learning Experiences in a Canada University During the COVID-19 Pandemic. Journal of English Language Teaching and Applied Linguistics, 3(5), 32-44.

Kapasia, N., Paul, P., Roy, A., Saha, J., Zaveri, A., Mallick, R., ... \& Chouhan, P. (2020). Impact of lockdown on learning status of undergraduate and postgraduate students during COVID-19 pandemic in West Bengal, India. Children and Youth Services Review, 116, 105194.

Karuppannan, S., \& Mohammed, L. A. (2020). Predictive Factors Associated with Online Learning during Covid-19 Pandemic in Malaysia: A Conceptual Framework. International Journal of Management and Human Science (IJMHS), 4(4), 19-29.

Katzenmeyer, M., \& Moller, G. (2001). Awakening the sleeping giant: Helping teachers develop as leaders. Newbury Park, CA: Corwin Press.

Khachfe, H. H., Chahrour, M., Sammouri, J., Salhab, H., Makki, B. E., \& Fares, M. (2020). An epidemiological study on COVID-19: a rapidly spreading disease. Cureus, 12(3).

Khairah N. K. (2020). "Edu Ministry Introduces Guidelines on Online Teaching, Learning Platforms". New Straits Times, 28 March 2020.

https://www.nst.com.my/news/nation/2020/03/578945/edu-ministryintroducesguidelines-online-teaching-learning-platforms. 
Krashen, S. (1982). Principles And Practice In Second Language Acquisition. Oxford: Pergamon Press.

Lassoued, Z., Alhendawi, M., \& Bashitialshaaer, R. (2020). An exploratory study of the obstacles for achieving quality in distance learning during the COVID-19 pandemic. Education Sciences, 10(9), 232.

Lestiyanawati, R., \& Widyantoro, A. (2020). Strategies and Problems Face by Indonesian Teachers in Conducting E-Learning System during COVID-19 Outbreak. Journal of Culture, Literature, Linguistics and English Teaching, 2, 71-82.

Li, H. O. Y., \& Bailey, A. M. (2020). Medical education amid the COVID-19 pandemic: new perspectives for the future. Academic Medicine.

Mailizar, Almanthari, A., Maulina, S., \& Bruce, S. (2020). Secondary School Mathematics Teachers' Views on E-learning Implementation Barriers during the Covid-19 Pandemic: The case of Indonesia. Eurasia Journal of Mathematics, Science and Technology Education, 2020, 16(7).

Moralista, R. B., \& Oducado, R. M. (2020). Faculty Perception toward Online Education in a State College in the Philippines during the Coronavirus Disease 19 (Covid-19) Pandemic. Universal Journal of Educational Research 8 (10), 4736 - 4742.

Marshall, A. L., \& Wolanskyj-Spinner, A. (2020). COVID-19: challenges and opportunities for educators and generation Z students. In Mayo Clinic Proceedings (Vol. 95, No. 6, pp. 1135-1137).

Mishra, L., Gupta, T., \& Shree, A. (2020). Online Teaching-Learning in Higher Education during Lockdown Period of COVID-19 Pandemic. International Journal of Education Research Open, 1, 100012.

Moore, R. L. (2016). Interacting at a distance: Creating engagement in online learning environments. In L. Kyei-Blankson, J. Blankson, E. Ntuli, \& C. Agyeman (Eds.), Handbook of Research on Strategic Management of Interaction, Presence, and Participation in Online Courses: IGI Global

Muin, N. A. (2021). Supporting And Engaging Isolated Language Students In Open And Distance Learning (Odl) Classes: A Comparative Study Between A Malaysian And An Indonesian University Undergraduate Students. In E-proceedings (P. 410).

Murgatrotd, S. (2020, March). COVID-19 and Online learning, Alberta, Canada. Doi:10.13140/RG.2.2.31132.85120

Niemi, H. M., \& Kousa, P. (2020),' A Case Study of Students' and Teachers' Perceptions in a Finnish High School during the COVID Pandemic', International Journal of Technology in Education and Science., vol. 4, no. 4 , pp. 352-369

Norlin, K. (2020). COVID-19: Impak Pandemik Kepada Ekonomi Dan Dasar Pemulihan. Retrieved from: https://www.bernama.com/bm/news.php?id=1829721

Nursalina \& Fitrawati. (2021). EFL Teachers' Perception on English Online Learning Activities during the Pandemic at High Schools in Padang. Journal of English Language Teaching, 10(2), 204-223, DOI: 10.24036/jelt.v10i2.112341

Okoli, C. (2015). A Guide to Conducting a Standalone Systematic To Cite This Version : A Guide to Conducting a Standalone Systematic Literature Review. Communications of the Association for Information Systems 37: 879 - 910.

Omar, N., \& Hashim, H. (2021). A Survey on the Acceptance of E-Learning for Professional Development amongst English as a Second Language (ESL) Teachers in Malaysia. Creative Education, 12, 1027-1039. 
Orhan, G., \& Beyhan, O. (2020). Teachers' Perceptions and Teaching Experiences on Distance Education Through Synchronous Video Conferencing during Covid-19 Pandemic. Social Sciences and Education Research Review Volume 7, Issue 1.

Paulsen, M. F. (2002). Online Education System: Discussion and Definition of Terms. Retrieved from:

https://www.porto.ucp.pt/open/curso/modulos/doc/Definition\%20of\%20Terms.pdf

Pokhrel, S., \& Chhetri, R. (2021). A literature review on impact of COVID-19 pandemic on teaching and learning. Higher Education for the Future, 8(1), 133-141.

Rahayu, R. P., \& Wirza, Y. (2020). Teachers' Perception of Online Learning during Pandemic Covid-19. Jurnal Penelitian Pendidikan. Volume 20, Nomor 3, 392-406.

Rakhmanina, L., Martina, F., Halolo, F. B., Syafryadin, S., \& Noermanzah, N. (2020). Students' Perception on Online English Learning during Covid-19 Pandemic Era. Silampari Bisa: Jurnal Penelitian Pendidikan Bahasa Indonesia, Daerah, Dan Asing, 3(2), 428-439.

Rasit, A. H., Ujir, H., Jen, C. C., Sapawi, R., \& Hipiny, I. (2021). Wide Survey on Online Teaching and Learning During Movement Control Order in Malaysia due to Covid-19 Pandemic.

Rasmitadila, Aliyyah, R. R., Rachmadtullah, R., Samsudin, A., Syaodih, E., Nurtanto, M., \& Tambunan, A. R. (2020). The Perceptions of Primary School Teachers of Online Learning during the COVID-19 Pandemic Period: A Case Study in Indonesia. Journal of Ethnic and Cultural Studies 2020, Vol. 7, No. 2, 90-109.

Raziq, A., \& Maulabakhsh, R. (2015). Impact of Working Environment on Job Satisfaction. Procedia Economics and Finance, 23, 717-725.

Sevy-Biloon, J. (2021). Virtual or face to face classes: Ecuadorian university students' perceptions during the pandemic. English Language Teaching Educational Journal, $4(1), 15-24$.

Shahzad, S. K., Hussain, J., Sadaf, N., Sarwat, S., Ghani, U., \& Saleem, R. (2020). Impact of Virtual Teaching on ESL Students' Attitudes under COVID-19 Circumstances at Postgraduate Level in Pakistan. English Language Teaching, 13(9), 1-9.

Silva, O., Sousa, Á. (2020). Perception of Teachers and Students about Teaching and Learning in the period of Covid-19 pandemic. In ICERI2020 Proceedings: 13th International Conference of Education, Research and Innovation (ICERI2020) (pp. 4832-4838).

Simanjuntak, U. S., Silalahi, D. E., Sihombing, P. S. R., \& Purba, L. (2021). Students' perceptions of using YouTube as English online learning media during Covid-19 pandemic, JOLLT Journal of Languages and Language Teaching, 9(2), 150-159

Sintema, E. J. (2020). Effect of COVID-19 on the performance of grade 12 students: Implications for STEM education. EURASIA Journal of Mathematics, Science and Technology Education, 16(7). https://doi.org /10.29333/ejmste/7893

Syahrin, S., \& Salih, A. A. (2020). An ESL Online Classroom Experience in Oman during Covid-19. Arab World English Journal, 11 (3) 42-55

Toquero, C. M. (2021). Emergency remote education experiment amid COVID-19 pandemic. IJERI: International Journal of Educational Research and Innovation, (15), 162-176.

UNESCO. (2020). COVID-19 Educational Disruption and Response. https://en.unesco.org/covid19/educationresponse (accessed on 1 June 2020)

USDLA (US American Distance Education Association). (2004) Definition of Distance Learning. Retrieved from: http//www.usdla.org/ 
Yunus, M. M., Ang, W. S., \& Hashim, H. (2021). Factors affecting teaching English as a Second Language (TESL) postgraduate students' behavioural intention for online learning during the COVID-19 pandemic. Sustainability, 13(6), 3524.

Wasley, P. (1991). Teachers who lead: The rhetoric of reform and the realities of practice. New York, NY: Teachers College Press.

Wazzan, M. (2020). 15 minutes of Fame: Online learning in the Coronavirus era. Al-Fanar Media. Retrieved from: https://www.al-fanarmedia.org/2020/04/15-minutes-offame-onlinelearning-in-the-coronavirus-era/

World Bank. (2020). Understanding Poverty. How countries are using edtech (including online learning, radio, television, texting) to support access to remote learning during the COVID-19 pandemic. Retrieved from https://www.worldbank.org/en/topic/edutech/brief/how-countries-are-usingedtech-to-support-remote-learning-during-the-covid-19-pandemic

WHO. (2020). Coronavirus disease 2019 Report (COVID-19), Situation Report - 59. Retrieved from: https://www.who.int/docs/defaultsource/coronaviruse/situationreports/20200319-sitrp-59-covid-19.pdf?sfvrsn=c3dcdef9_2

Yen, E. L. Y., \& Mohamad, M. (2021). Spelling Mastery via Google Classroom among Year 4 Elementary School ESL Students during the COVID-19 Pandemic. Journal of Education and e-Learning Research, 8(2), 206-215.

Yew, K. K. W., \& Tan, K. H. (2020). ESL Teachers' Intention in Adopting Online Educational Technologies during COVID-19 Pandemic. Journal of Education and e-Learning Research, 7(4): 387-394.

Yunus, M. M., Ang, W. S., \& Hashim, H. (2021). Factors Affecting Teaching English as a Second Language (TESL) Postgraduate Students' Behavioural Intention for Online Learning during the COVID-19 Pandemic. Sustainability, 13(6), 1-14.

Zarzycka-Piskorz, E. (2016). Kahoot it or not? Can games be motivating in learning grammar? Teaching English with Technology, 16(3), 17-36.

Zwain, A. A. A. (2019). Technological innovativeness and information quality as neoteric predictors of users' acceptance of learning management system: An expansion of UTAUT2. Interactive Technology and Smart Education, 16(3), 239-254. https://doi.org/10.1108/ITSE-09-2018-0065 